Keywords: DWPF, PCCS, $\mathrm{MCU}$, glass, boric acid, frit

Retention: Permanent

\title{
The Impact of the MCU Life Extension Solvent on DWPF Glass Formulation Efforts
}

D.K. Peeler

T.B. Edwards

March 2011

Savannah River National Laboratory Savannah River Nuclear Solutions Aiken, SC 29808

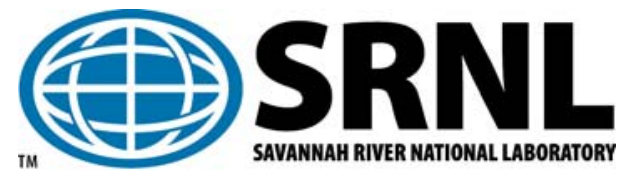


SRNL-STI-2011-00110

Revision 0

\section{DISCLAIMER}

This work was prepared under an agreement with and funded by the U.S. Government. Neither the U.S. Government or its employees, nor any of its contractors, subcontractors or their employees, makes any express or implied:

1. warranty or assumes any legal liability for the accuracy, completeness, or for the use or results of such use of any information, product, or process disclosed; or 2. representation that such use or results of such use would not infringe privately owned rights; or

3. endorsement or recommendation of any specifically identified commercial product, process, or service.

Any views and opinions of authors expressed in this work do not necessarily state or reflect those of the United States Government, or its contractors, or subcontractors.

\section{Printed in the United States of America \\ Prepared for U.S. Department of Energy}




\section{REVIEWS AND APPROVALS}

AUTHORS:

D.K. Peeler, Process Technology Programs

Date

T.B. Edwards, Applied Computational Engineering and Statistics

Date

TECHNICAL REVIEWERS:

K.M. Fox, Process Technology Programs

Date

M.E. Stone, Process Technology Programs

Date

J.D. Newell, Process Technology Programs

Date

APPROVALS:

C.C. Herman, Manager

Date

Process Technology Programs

A.B. Barnes, Manager

Date

Engineering Process Development

S.L. Marra, Manager

Date

Environmental \& Chemical Process Technology Research Programs

J.E. Occhipinti, Manager

Date

Waste Solidification Engineering 


\section{ACKNOWLEDGEMENTS}

The authors would like to thank Allan Barnes, Connie Herman, Michael Stone, and David Newell for their technical guidance and insightful technical discussions. The authors would also like to acknowledge the technical support provided by Pat Simmons and Phyllis Workman for glass fabrication and the physical property measurements. 


\section{EXECUTIVE SUMMARY}

As a part of the Actinide Removal Process (ARP)/Modular Caustic Side Solvent Extraction Unit (MCU) Life Extension Project, a next generation solvent (NG-CSSX), a new strip acid, and modified monosodium titanate (mMST) will be deployed. The strip acid will be changed from dilute nitric acid to dilute boric acid $(0.01 \mathrm{M})$. Because of these changes, experimental testing with the next generation solvent and mMST is required to determine the impact of these changes in 512-S operations as well as Chemical Process Cell (CPC), Defense Waste Processing Facility (DWPF) glass formulation activities, and melter operations at DWPF.

To support programmatic objectives, the downstream impacts of the boric acid strip effluent (SE) to the glass formulation activities and melter operations are considered in this study. More specifically, the impacts of boric acid additions to the projected SB7b operating windows, potential impacts to frit production temperatures, and the potential impact of boron volatility are evaluated. Although various boric acid molarities have been reported and discussed, the baseline flowsheet used to support this assessment was $0.01 \mathrm{M}$ boric acid.

The results of the paper study assessment indicate that Frit 418 and Frit 418-7D are robust to the implementation of the $0.01 \mathrm{M}$ boric acid SE into the SB7b flowsheet (sludge-only or ARP-added). More specifically, the projected operating windows for the nominal SB7b projections remain essentially constant (i.e., $25-43$ or $25-44 \%$ waste loading (WL)) regardless of the flowsheet options (sludge-only, ARP added, and/or the presence of the new SE). These results indicate that even if SE is not transferred to the Sludge Receipt and Adjustment Tank (SRAT), there would be no need to add boric acid (from a trim tank) to compositionally compensate for the absence of the boric acid SE in either a sludge-only or ARP-added SB7b flowsheet.

With respect to boron volatility, the Measurement Acceptability Region (MAR) assessments also suggest that Slurry Mix Evaporator (SME) acceptability decisions would not be different assuming either $100 \%$ of the $\mathrm{B}_{2} \mathrm{O}_{3}$ from the $\mathrm{SE}$ were retained or volatilized. More specifically, the $0.84 \mathrm{wt} \% \mathrm{~B}_{2} \mathrm{O}_{3}$ in the SE is so minor that its presence in the SME analysis does not influence SME acceptability decisions. In fact, using the $100 \%$ retention and $100 \%$ volatilization composition projections, only minor differences in the predicted properties of the glass product occur with all of the glasses being acceptable over a WL interval of 32-42\%.

Based on the $0.01 \mathrm{M}$ boric acid flowsheet, there is very little difference between Frit 418 and Frit 418-7D (a frit that was compositionally altered to account for the $0.84 \mathrm{wt} \% \mathrm{~B}_{2} \mathrm{O}_{3}$ in the SE) with respect to melt temperature. In fact, when one evaluates the composition of Frit 418-7D, it lies within the current Frit 418 vendor specifications and therefore could have been produced by the vendor targeting the nominal composition of Frit 418. 


\section{TABLE OF CONTENTS}

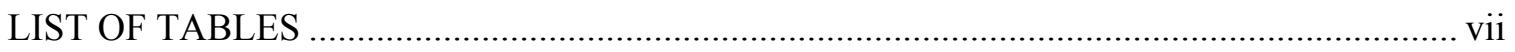

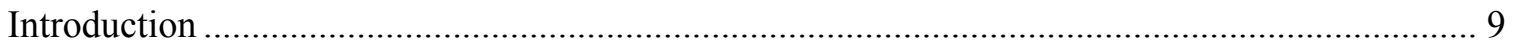

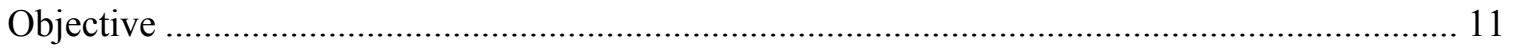

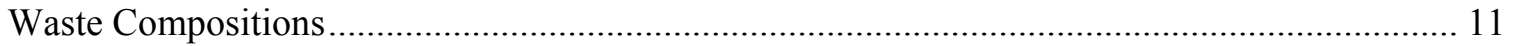

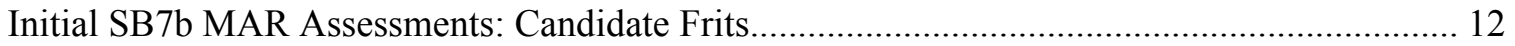

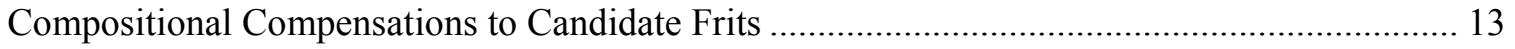

SB7b Sludge Compositions with 0.84 wt $\% \mathrm{~B}_{2} \mathrm{O}_{3}$ Additions................................................... 14

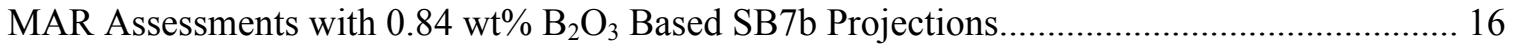

MAR Assessment Results with > 0.84 wt $\% \mathrm{~B}_{2} \mathrm{O}_{3}$ Additions to SB7b Projections ....................... 18

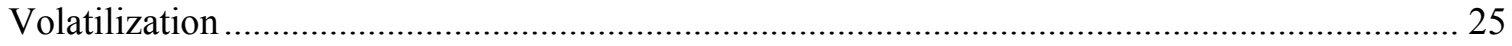

MAR Assessment: Impact of $\mathrm{B}_{2} \mathrm{O}_{3}$ Volatility on Predicted Properties and SME Acceptability

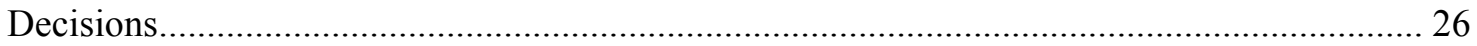

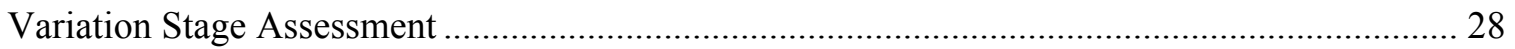

Impact of Frit 418 Specifications on Projected Operating Windows ............................................. 29

Impact $\mathrm{B}_{2} \mathrm{O}_{3}$ Reduction on Frit Melt Temperatures ................................................................. 32

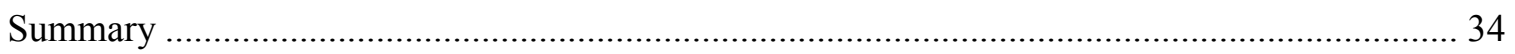

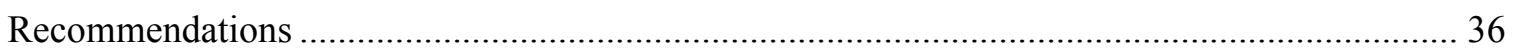

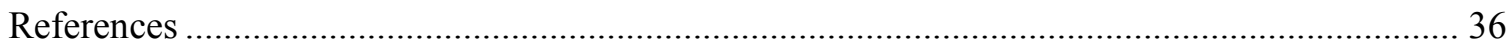




\section{LIST OF TABLES}

Table 1. Nominal Projections (Sludge-Only and ARP Added) for SB7b (1-20-11 Projections) (wt $\%$, calcined oxides).

Table 2. Projected Operating Windows for Sludge-Only and Coupled Operations SB7b Projections with Frit 418.

Table 3. Percentage of $\mathrm{B}_{2} \mathrm{O}_{3}$ in Frit Contained in SE as a Function of Volume Added to SRAT for the 0.01M Boric Acid Baseline Flowsheet [from Stone (2010)].

Table 4. Nominal Compositions (wt \%) of Frit 418 and Frit 418-7D. 14

Table 5. Nominal SB7b April Projections (wt $\%$, calcined oxides) with $0.84 \mathrm{wt} \% \mathrm{~B}_{2} \mathrm{O}_{3}$ 15

Table 6. Nominal SB7b May Projections (wt $\%$, calcined oxides) with $0.84 \mathrm{wt} \% \mathrm{~B}_{2} \mathrm{O}_{3}$ 16

Table 7. Projected Operating Windows for the SB7b Projections with and without the $0.84 \mathrm{wt} \%$ $\mathrm{B}_{2} \mathrm{O}_{3}$ Addition with Frit 418 and Frit 418-7D.

Table 8. Nominal SB7b Projections (wt $\%$, calcined oxides) with $0.9 \mathrm{wt} \% \mathrm{~B}_{2} \mathrm{O}_{3}$ Addition......... 20

Table 9. Nominal SB7b Projections (wt $\%$, calcined oxides) with $1.0 \mathrm{wt} \% \mathrm{~B}_{2} \mathrm{O}_{3}$ Additions. ...... 21

Table 10. Nominal SB7b Projections (wt $\%$, calcined oxides) with $2.0 \mathrm{wt} \% \mathrm{~B}_{2} \mathrm{O}_{3}$ Additions. .... 22

Table 11. Projected Operating windows for the April SB7b Projections with $\mathrm{B}_{2} \mathrm{O}_{3}$ Additions of $0.84,0.9,1.0$, and $2.0 \mathrm{wt} \%$.

Table 12. Projected Operating windows for the May SB7b Projections with $\mathrm{B}_{2} \mathrm{O}_{3}$ Additions of $0.84,0.9,1.0$, and $2.0 \mathrm{wt} \%$.

Table 13. Predicted Properties and MAR Status for $100 \%$ Retention and $100 \%$ Volatility of $\mathrm{B}_{2} \mathrm{O}_{3}$ from the $\mathrm{SE}$ at $40 \% \mathrm{WL}$ 26

Table 14. MAR Status for $100 \%$ Retention and $100 \%$ Volatility of $\mathrm{B}_{2} \mathrm{O}_{3}$ from the SE over WLs of $32-42 \%$ for the May-Based SB7b Projections.

Table 15. Variation Stage MAR Assessments for Frit 418 and Frit 418-7D. 29

Table 16. Nominal Compositions (wt\%) of Frit 418 and Frit 418-7D with current Frit

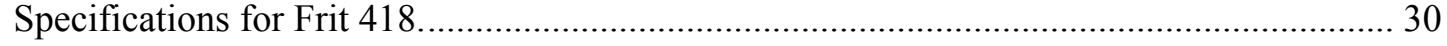

Table 17. Projected Operating Windows for Frit 418 EVs for April-Based SB7b Projections. ... 31

Table 18. Projected Operating Windows for Frit 418 EVs for May-Based SB7b Projections...... 32

Table 19. Nominal Compositions of Frit 418, Frit 418-7D, and Frit 418-75D........................... 33

Table 20. High Temperature Viscosity Measurements for Frit 418 .......................................... 34 


\section{LIST OF ABBREVIATIONS}

\begin{tabular}{|c|c|}
\hline ARP & Actinide Removal Process \\
\hline $\mathrm{CPC}$ & Chemical Process Cell \\
\hline DOE & Department of Energy \\
\hline DWPF & Defense Waste Processing Facility \\
\hline EA & Environmental Assessment \\
\hline EDS & Energy Dispersive Spectroscopy \\
\hline EDM & Electrical Discharge Machining \\
\hline HLW & High Level Waste \\
\hline MAR & Measurement Acceptability Region \\
\hline $\mathrm{MCU}$ & Modular Caustic Side Solvent Extraction Unit \\
\hline mMST & Modified Monosodium Titanate \\
\hline NG & Next Generation \\
\hline PCCS & Product Composition Control System \\
\hline PCT & Product Consistency Test \\
\hline SB & Sludge Batch \\
\hline SE & Strip Effluent \\
\hline SEM & Scanning Electron Microscopy \\
\hline SME & Slurry Mix Evaporator \\
\hline SPF & Saltstone Processing Facility \\
\hline SRAT & Sludge Receipt and Adjustment Tank \\
\hline SRNL & Savannah River National Laboratory \\
\hline SRS & Savannah River Site \\
\hline SWPF & Salt Waste Processing Facility \\
\hline $\mathrm{T}_{\mathrm{L}}$ & Liquidus Temperature \\
\hline TTR & Technical Task Request \\
\hline TTQAP & Task Technical and Quality Assurance Plan \\
\hline$\eta$ & Viscosity \\
\hline WL & Waste Loading \\
\hline
\end{tabular}




\section{Introduction}

The Actinide Removal Process (ARP)/Modular Caustic Side Solvent Extraction Unit (MCU) Life Extension includes activities required to support ARP/MCU extended operations to treat dissolved salt cake waste (i.e., remove actinides, strontium, and cesium) and deliver a lowactivity decontaminated salt solution waste stream to the Saltstone Processing Facility (SPF). The resulting cesium and actinide/strontium salt stream is processed in the Defense Waste Processing Facility (DWPF). As a part of the ARP/MCU Life Extension Project, a next generation solvent (NG-CSSX), a new strip acid, and modified monosodium titanate (mMST) will be deployed. The strip acid will be changed from dilute nitric acid to dilute boric acid (0.01 $\mathrm{M})$. Because of these changes, experimental testing with the next generation solvent and mMST is required to determine the impact of these changes in 512-S operations as well as Chemical Process Cell (CPC), DWPF glass formulation activities, and melter operations at DWPF.

Bricker [2010] issued a Technical Task Request (TTR) to support the assessments of the impact of the next generation solvent and mMST on the downstream DWPF flowsheet unit operations (i.e., CPC, glass formulation, and melter operations). Newell and Peeler [2011] issued a Task Technical and Quality Assurance Plan (TTQAP) in response to the TTR which outlined the technical approach to be used to meet programmatic objectives. To support programmatic objectives, the downstream impacts of the boric acid strip effluent (SE) to the glass formulation activities and melter operations are considered in this study. More specifically, the impacts of boric acid additions to the projected Sludge Batch $7 \mathrm{~b}$ (SB7b) operating windows ${ }^{1}$, potential impacts to frit production temperatures, and the potential impact of boron volatility are evaluated. The impacts to CPC processing will be documented in a separate report. It should be noted that although various boric acid molarities have been reported and discussed [Stone (2010)], the baseline flowsheet used to support this assessment is a $0.01 \mathrm{M}$ boric acid concentration. As warranted, increased levels of boric acid $\left(\mathrm{B}_{2} \mathrm{O}_{3}\right)$ additions were also evaluated but these higher concentrations should be considered outside the current baseline flowsheet.

As outlined in the TTQAP, the introduction of the dilute $(0.01 \mathrm{M})$ boric acid stream into the DWPF flowsheet has a potential impact on glass formulation and frit development efforts, which centers around the fact that $\mathrm{B}_{2} \mathrm{O}_{3}$ is a major oxide in frits developed for DWPF. Introduction of the boric acid in an upstream unit operation may require compositional adjustments to the frit to ensure both process and product performance properties are maintained during production. Process control models are used to predict key glass properties as a function of glass composition (based on compositional analysis of the Slurry Mix Evaporator (SME) sample). These predicted properties are then compared to pre-defined constraints to determine the acceptability of the melter feed. If all of the glass properties simultaneously satisfy the constraints, the glass is deemed acceptable and the melter feed is transferred to the melter. One of the questions to be addressed in this study is the robustness of the flowsheet to upstream additions of $\mathrm{B}_{2} \mathrm{O}_{3}$ on $\mathrm{SME}$ acceptability decisions. That is, with the introduction of the new solvent (or boric acid) stream into the DWPF flowsheet, it is imperative that the impacts of this stream are identified so that compositional adjustments can be made to the frit to account for this new stream or it must be

\footnotetext{
${ }^{1}$ The TTR specified that if projections of SB7b were available that those compositions be used to support the glass formulation assessments. Based on recent MAR assessments, Frit 418 was identified as a viable candidate for processing SB7b and will be used in this assessment given its historical use in DWPF. Use of Frit 418 in this assessment should not be viewed as a frit recommendation for SB7b processing given other viable frits were also identified.
} 
demonstrated that the glass system is robust to these compositional perturbations and no changes to the glass formulation approach are warranted.

Key areas to be addressed in this report are associated with the potential impact of the new SE (boric acid) on DWPF glass formulation include: (1) ensuring potential impacts to future SME acceptability decisions are identified and, if warranted, outlining strategies or approaches to technically address those impacts, (2) assessing the robustness of the candidate frits to potential sludge compositional variations (sludge-only operations, coupled operations based on ARP additions, or introduction of the new SE into the DWPF flowsheet), (3) evaluating the impact of potential boric acid (or boron) volatility during vitrification of the SME product or during melter processing on key glass properties or SME acceptability decisions, and (4) evaluating the impact on the nominal melting temperatures of candidate frit compositions that may require compositional alterations (e.g., reduction in $\mathrm{B}_{2} \mathrm{O}_{3}$ content) to account for the new SE.

These key technical areas will be addressed through two separate but interrelated tasks. The first task will address the overarching questions associated with the impact of the new SE on future SME acceptability decisions. For example, if introduction of the boron-containing SE into the DWPF flowsheet results in significant differences with respect to SME acceptability decisions, this could dictate compositional adjustments to the frit to maintain access to contractual waste loading (WL) targets. If dramatic compositional adjustments to historical frits (such as Frit 418) are required, this in turn raises questions about the ability of current frit vendors to produce a boron-deficient frit using existing melter technologies. As defined by Stone [2010], the magnitude of the frit compositional alterations (relative to Frit 418) ultimately depends on the molarity of the SE (i.e., $0.01 \mathrm{M}$ versus $0.5 \mathrm{M}$ ) and the volume of SE added per Sludge Receipt and Adjustment Tank (SRAT) batch.

To assess the impact of the introduction of the new SE on future SME acceptability decision, Nominal and Variation Stage Measurement Acceptability Region (MAR) assessments developed by the Savannah River National Laboratory (SRNL) [Peeler and Edwards (2005)] will be used. Per the TTR, the MAR assessments will use the most recent projections of Sludge Batch 7b (SB7b) from Savannah River Remediation (SRR). Recent MAR assessments identified Frit 418 as a viable candidate for processing of SB7b. ${ }^{2}$ Specific items to be addressed in the MAR assessments include:

(1) Defining and comparing projected operating windows for the various potential SB7b flowsheets based on sludge-only, coupled operations (including ARP), and the introduction of the boron acid SE.

(2) Assessing whether Frit 418 is robust to the potential perturbations in the flowsheet. That is, if sludge-only is being processed and then ARP and the new SE is introduced, will Frit 418 provide access to WLs of interest? Or will a different frit be required? Can a single frit be identified to handle the possible composition differences that may be introduced into the SRAT (i.e., sludge-only processing, coupled operations, and introduction of the new SE with either flowsheet)? Or will a source of $\mathrm{B}_{2} \mathrm{O}_{3}$ (boric acid) be required to trim SRAT batches in which the new $\mathrm{SE}$ is not introduced but the frit has been designed for?

\footnotetext{
${ }^{2}$ Initial projections for SB7b were provided to SRNL on 1-20-11 through a personal communication from D. Mcimoyle of Savannah River Remediation (SRR). For more details on the SB7b projections (which included projections based on SB6 end dates of April 1 and May 31, 2010 - two nominal projections provided), see SRNL-NB-2010-00108, pp. 92 94. SRNL performed MAR assessments on these projections (with and without ARP additions) and provided feedback to SRR on February 2, 2011 (see SRNL-NB-2010-00108, pp. 96-97 for more details). It should be noted that the impact of the new SE was not accounted for in the initial MAR assessments.
} 
(3) Evaluating the impact of the current Frit 418 specifications on the projected operating windows. More specifically, how robust is the SB7b flowsheet to not only possible variation in the incoming waste streams (e.g., sludge-only, ARP, and boric acid) but do the current frit specifications need to be changed? Current vendor specifications for $\mathrm{B}_{2} \mathrm{O}_{3}$ in Frit 418 are $8 \pm 0.65 \mathrm{wt} \%$.

(4) Evaluating the impact of boron volatility in either the SME acceptability process (during conversion of the SME product to a glass which is ultimately used to obtain predicted properties) or during processing of the feed through the melter.

In addition to the MAR assessment paper studies, the second task will be experimentally based to assess the potential impact on required melt temperatures for boron-deficient frits. If a significant fraction of the $\mathrm{B}_{2} \mathrm{O}_{3}$ is introduced through the new $\mathrm{SE}$, major reductions in the $\mathrm{B}_{2} \mathrm{O}_{3}$ content of candidate frits may be required to maintain access to contractual WL targets. As mentioned by Stone [2010], removal of $\mathrm{B}_{2} \mathrm{O}_{3}$ from the frit could result in an increase in the required frit melt temperature (given $\mathrm{B}_{2} \mathrm{O}_{3}$ is a fluxing agent). Bricker [2010] requested information regarding potential melt temperature differences as a function of the amount of $\mathrm{B}_{2} \mathrm{O}_{3}$ that could potentially be removed from candidate frits. This information is desired to ensure the current frit vendors have existing technologies to manufacture boron-deficient frits. As previously mentioned, the percent of $\mathrm{B}_{2} \mathrm{O}_{3}$ to be removed will depend on the molarity and volume of the boric acid SE ultimately introduced into the flowsheet. Again, for the purposes of this study, it is assumed that the $0.01 \mathrm{M}$ boric acid flowsheet serves as the baseline while assessment of higher $\mathrm{B}_{2} \mathrm{O}_{3}$ contents should be considered exploratory in nature.

\section{Objective}

The objective of this report is to document the downstream impacts of the new SE $(0.01 \mathrm{M}$ boric acid) to glass formulation, frit development, SME acceptability decisions, and melter operations (with respect to boron volatility). The impacts to 512-S operations and CPC processing will be documented in separate reports.

\section{Waste Compositions}

Given the introduction of the new SE could occur during SB7b processing, the latest projections of SB7b were to be used to support this assessment. Table 1 summarizes the SB7b projections from SRR received on January 20, 2011. The two nominal sludge-only SB7b projections (labeled SB7b (April) and SB7b (May)) are based on different projected end dates for SB6 (April 1 and May 31, 2011 respectively). Table 1 also shows the addition of the ARP stream to the two nominal sludge-only projections received from SRR. ${ }^{3}$ These SB7b compositions served as the basis for a recent paper study performed by SRNL and will be used as the baseline for the current study.

\footnotetext{
${ }^{3}$ Nominal coupled operations projections are based on introduction of the Actinide Removal Process (ARP) stream from S.G. Subosits, “Actinide Removal Process Material Balance Calculation with Low Curie Salt Feed," X-CLC-S00113 Rev 0, Appendix J, September 24, 2004.

${ }^{4}$ SRNL performed MAR assessments on these projections (with and without ARP additions) and provided feedback to SRR on February 2, 2011 (see SRNL-NB-2010-00108, pp. 96-97 for more details).
} 
Table 1. Nominal Projections (Sludge-Only and ARP Added) for SB7b (1-20-11 Projections) (wt\%, calcined oxides).

\begin{tabular}{|c|c|c|c|c|}
\hline & $\begin{array}{c}\text { SB7b } \\
\text { (April) }\end{array}$ & $\begin{array}{c}\text { SB7b ARP } \\
\text { (April) }\end{array}$ & $\begin{array}{l}\text { SB7b } \\
\text { (May) }\end{array}$ & $\begin{array}{c}\text { SB7b ARP } \\
\text { (May) }\end{array}$ \\
\hline $\mathrm{Al}_{2} \mathrm{O}_{3}$ & 20.51 & 19.67 & 20.22 & 19.38 \\
\hline $\mathrm{BaO}$ & 0.11 & 0.11 & 0.11 & 0.11 \\
\hline $\mathrm{CaO}$ & 1.08 & 1.07 & 1.05 & 1.04 \\
\hline $\mathrm{Ce}_{2} \mathrm{O}_{3}$ & 0.13 & 0.13 & 0.13 & 0.13 \\
\hline $\mathrm{Cr}_{2} \mathrm{O}_{3}$ & 0.30 & 0.29 & 0.30 & 0.29 \\
\hline $\mathrm{CuO}$ & 0.06 & 0.06 & 0.06 & 0.06 \\
\hline $\mathrm{Fe}_{2} \mathrm{O}_{3}$ & 27.67 & 26.71 & 27.74 & 26.78 \\
\hline $\mathrm{K}_{2} \mathrm{O}$ & 0.18 & 0.18 & 0.20 & 0.19 \\
\hline $\mathrm{La}_{2} \mathrm{O}_{3}$ & 0.08 & 0.08 & 0.08 & 0.08 \\
\hline $\mathrm{MgO}$ & 0.62 & 0.59 & 0.62 & 0.59 \\
\hline $\mathrm{MnO}$ & 5.43 & 5.35 & 5.37 & 5.29 \\
\hline $\mathrm{Na}_{2} \mathrm{O}$ & 25.65 & 26.17 & 25.68 & 26.20 \\
\hline $\mathrm{NiO}$ & 4.43 & 4.25 & 4.49 & 4.31 \\
\hline $\mathrm{PbO}$ & 0.04 & 0.05 & 0.04 & 0.05 \\
\hline $\mathrm{RuO}_{2}$ & 0.00 & 0.01 & 0.00 & 0.01 \\
\hline $\mathrm{SO}_{4}$ & 1.50 & 1.55 & 1.49 & 1.55 \\
\hline $\mathrm{SiO}_{2}$ & 3.38 & 3.22 & 3.44 & 3.28 \\
\hline $\mathrm{ThO}_{2}$ & 0.46 & 0.44 & 0.50 & 0.47 \\
\hline $\mathrm{TiO}_{2}$ & 0.03 & 1.32 & 0.03 & 1.32 \\
\hline $\mathrm{U}_{3} \mathrm{O}_{8}$ & 7.96 & 7.67 & 8.10 & 7.80 \\
\hline $\mathrm{ZnO}$ & 0.08 & 0.08 & 0.06 & 0.06 \\
\hline $\mathrm{ZrO}_{2}$ & 0.28 & 0.27 & 0.27 & 0.27 \\
\hline $\mathrm{Cl}$ & 0.00 & 0.60 & 0.00 & 0.60 \\
\hline $\mathrm{F}$ & 0.00 & 0.10 & 0.00 & 0.10 \\
\hline $\mathrm{I}$ & 0.00 & 0.02 & 0.00 & 0.02 \\
\hline
\end{tabular}

\section{Initial SB7b MAR Assessments: Candidate Frits}

Based on the initial MAR assessment results, Frit 418 (out of approximately 2900 candidate frits) was identified as a viable (not optimal) candidate for processing all four SB7b projections shown in Table 1..$^{5}$ The projected operating windows (i.e., the WL interval over which all glass compositions simultaneously satisfy the PCCS constraints) for these four nominal SB7b projections when coupled with Frit 418 are summarized in Table 2. The results of the Nominal Stage MAR assessment indicated that the projected operating windows were $25 \%$ WL to either $42 \%$ or $43 \% \mathrm{WL}$ for these four projections. Given a contractual WL target of $36 \%$, Frit 418 is considered a viable candidate for SB7b processing.

\footnotetext{
${ }^{5}$ Based on the initial MAR assessment, four frits were identified that provided projected operating windows of $25-43 \%$ WL for all four sludge options. Based on this result, Frit 418 is considered viable but not "optimal".
} 
The results of this initial MAR assessment not only provide a frit composition to be used (Frit 418) but also provide baseline projected operating windows from which the impacts of the boric acid SE can be compared.

Table 2. Projected Operating Windows for Sludge-Only and Coupled Operations SB7b Projections with Frit 418.

\begin{tabular}{||c|c||}
\hline SB7b Sludge Option & $\begin{array}{c}\text { Projected Operating } \\
\text { Window }\end{array}$ \\
\hline SB7b (April) & $25-43 \% \mathrm{WL}$ \\
\hline SB7b ARP (April) & $25-43 \% \mathrm{WL}$ \\
\hline SB7b (May) & $25-42 \% \mathrm{WL}$ \\
\hline SB7b ARP (May) & $25-43 \% \mathrm{WL}$ \\
\hline
\end{tabular}

\section{Compositional Compensations to Candidate Frits}

Based on the current baseline flowsheet of $0.01 \mathrm{M}$ boric acid, Stone [2010] calculated the percentage of frit boron (assuming Frit 418 with a $\mathrm{B}_{2} \mathrm{O}_{3}$ content of $8 \mathrm{wt} \%$ ) contained in the $\mathrm{SE}$ as a function of the amount of strip effluent added per SRAT batch. Table 3 summarizes a portion of the calculations provided by Stone [2010] as a function of the volume of SE added to the SRAT for the $0.01 \mathrm{M}$ boric acid baseline flowsheet. The percentage of boron in frit that is contained in the SE ranged from 0.5 to $6.9 \%$ for 5,000 and 70,000 liters of SE added to the SRAT, respectively. Given the $0.01 \mathrm{M}$ flowsheet is considered baseline and assuming 70,000 liters of SE per SRAT batch represents a bounding volume of SE to be added, the $6.9 \% \mathrm{~B}_{2} \mathrm{O}_{3}$ of Frit 418 that is contained in the SE will be used to assess the impact of the SE on future SME acceptability decisions. It should be noted that the $6.9 \%$ value is based not only on Frit 418's $\mathrm{B}_{2} \mathrm{O}_{3}$ content (nominally $8 \mathrm{wt} \%$ - see Table 4) but for a $40 \%$ WL glass. Based on these assumptions and the calculations by Stone [2010], approximately $0.56 \mathrm{wt} \%$ of Frit 418 's $\mathrm{B}_{2} \mathrm{O}_{3}$ will be introduced into the SRAT through addition of the new SE at 40\% WL.

Table 3. Percentage of $\mathrm{B}_{2} \mathrm{O}_{3}$ in Frit Contained in $\mathrm{SE}$ as a Function of Volume Added to SRAT for the 0.01M Boric Acid Baseline Flowsheet [from Stone (2010)].

\begin{tabular}{||l|c|c|c|c|l||}
\hline \hline Strip Effluent Added per SRAT Batch & 5,000 & 30,000 & 50,000 & 70,000 & liters \\
\hline Strip Effluent Added per SRAT Batch & 1321 & 7926 & 13210 & 18494 & gallons \\
\hline Amount of Boron in Strip Effluent & 50 & 300 & 500 & 700 & moles \\
\hline Amount of Boron in Strip Effluent & 1 & 3 & 5 & 8 & $\mathrm{~kg}$ \\
\hline Percentage of Boron in frit contained in SE & 0.5 & 3.0 & 4.9 & 6.9 & $\%$ \\
\hline
\end{tabular}

To evaluate the impact of the $\mathrm{SE}$ on the projected operating windows, the $\mathrm{B}_{2} \mathrm{O}_{3}$ content in the sludge (on a calcined oxide basis) must be determined. To accomplish this, the calculations by Stone [2010] based on Frit 418 at $40 \%$ WL were used as a basis. For example, a glass based on Frit 418 at $40 \%$ WL would have a $\mathrm{B}_{2} \mathrm{O}_{3}$ content of $4.8 \mathrm{wt} \%$ (assuming no $\mathrm{B}_{2} \mathrm{O}_{3}$ coming in from the sludge which is the case for the nominal SB7b projections shown in Table 1). If a $0.56 \mathrm{wt} \%$ 
$\mathrm{B}_{2} \mathrm{O}_{3}$-deficient Frit 418 (referred to as Frit 418-7D in Table 4) were used to counter the $\mathrm{B}_{2} \mathrm{O}_{3}$ addition from the boric acid stream, the $\mathrm{B}_{2} \mathrm{O}_{3}$ content in the sludge would have to be $\sim 0.84 \mathrm{wt} \%$ to yield the $4.8 \mathrm{wt} \% \mathrm{~B}_{2} \mathrm{O}_{3}$ in glass. More specifically, consider the $\mathrm{B}_{2} \mathrm{O}_{3}$-deficient Frit 418-7D when coupled with a SB7b sludge containing $0.84 \mathrm{wt} \% \mathrm{~B}_{2} \mathrm{O}_{3}$. At $40 \% \mathrm{WL}$, the $\mathrm{B}_{2} \mathrm{O}_{3}$ contribution from Frit 418-7D would be $4.464 \mathrm{wt} \%$ (or $7.44 \mathrm{wt} \%$ times $((100-\mathrm{WL}) / 100)$ ) while $0.336 \mathrm{wt} \%$ $\mathrm{B}_{2} \mathrm{O}_{3}$ would be introduced to the glass through the sludge $(0.84 \mathrm{wt} \%$ times 0.4$)$ for a total of 4.8 $\mathrm{wt} \% \mathrm{~B}_{2} \mathrm{O}_{3}$ in glass. Therefore, the addition of $0.84 \mathrm{wt} \% \mathrm{~B}_{2} \mathrm{O}_{3}$ (on a calcined oxide basis) to each of the nominal sludge projections will be used to support assessments of SME acceptability decisions.

Table 4. Nominal Compositions (wt\%) of Frit 418 and Frit 418-7D.

\begin{tabular}{||c|c|c||}
\hline Oxide & Frit 418 & Frit 418-7D \\
\hline $\mathbf{B}_{\mathbf{2}} \mathbf{O}_{3}$ & 8 & 7.44 \\
\hline $\mathbf{L i}_{\mathbf{2}} \mathbf{O}$ & 8 & 8.05 \\
\hline $\mathbf{N a}_{\mathbf{2}} \mathbf{O}$ & 8 & 8.05 \\
\hline $\mathrm{SiO}_{2}$ & 76 & 76.46 \\
\hline
\end{tabular}

\section{SB7b Sludge Compositions with 0.84 wt $\% \mathrm{~B}_{2} \mathrm{O}_{3}$ Additions}

To simulate the introduction of the boron-laded SE into the SRAT (at the maximum volume (70,000 liters) for the current $0.01 \mathrm{M}$ baseline), $0.84 \mathrm{wt} \% \mathrm{~B}_{2} \mathrm{O}_{3}$ was added to each of the nominal sludge-only and ARP-added waste streams (shown in Table 1) and the remaining components renormalized. Table 5 shows the SB7b projections based on the April 1, 2011 SB6 end date. Table 6 shows similar sludge projections using the May 31, 2011 SB6 end date projections. 
Table 5. Nominal SB7b April Projections (wt\%, calcined oxides) with 0.84 wt\% $\mathrm{B}_{2} \mathrm{O}_{3}$.

\begin{tabular}{|c|c|c|c|c|}
\hline & SB7b-April & $\begin{array}{c}\text { SB7b-April- } \\
\text { ARP }\end{array}$ & $\begin{array}{c}\text { SB7b-April } \\
\mathrm{B}_{2} \mathrm{O}_{3}-\mathbf{0 . 8 4}\end{array}$ & $\begin{array}{c}\text { SB7b-April- } \\
\text { ARP } \mathbf{B}_{2} \mathbf{O}_{3}-\mathbf{0 . 8 4}\end{array}$ \\
\hline $\mathbf{A l}_{2} \mathbf{O}_{3}$ & 20.51 & 19.67 & 20.34 & 19.50 \\
\hline $\mathbf{B}_{2} \mathbf{O}_{3}$ & 0.00 & 0.00 & 0.84 & 0.84 \\
\hline $\mathrm{BaO}$ & 0.11 & 0.11 & 0.11 & 0.11 \\
\hline $\mathrm{CaO}$ & 1.08 & 1.07 & 1.07 & 1.06 \\
\hline $\mathrm{Ce}_{2} \mathrm{O}_{3}$ & 0.13 & 0.13 & 0.13 & 0.13 \\
\hline $\mathrm{Cr}_{2} \mathrm{O}_{3}$ & 0.30 & 0.29 & 0.30 & 0.28 \\
\hline $\mathrm{CuO}$ & 0.06 & 0.06 & 0.06 & 0.06 \\
\hline $\mathrm{Fe}_{2} \mathrm{O}_{3}$ & 27.67 & 26.71 & 27.43 & 26.48 \\
\hline $\mathrm{K}_{2} \mathbf{O}$ & 0.18 & 0.18 & 0.18 & 0.18 \\
\hline $\mathrm{La}_{2} \mathbf{O}_{3}$ & 0.08 & 0.08 & 0.08 & 0.08 \\
\hline MgO & 0.63 & 0.59 & 0.62 & 0.59 \\
\hline MnO & 5.43 & 5.35 & 5.39 & 5.30 \\
\hline $\mathrm{Na}_{2} \mathrm{O}$ & 25.65 & 26.17 & 25.43 & 25.95 \\
\hline $\mathrm{NiO}$ & 4.43 & 4.25 & 4.40 & 4.21 \\
\hline PbO & 0.04 & 0.05 & 0.04 & 0.05 \\
\hline $\mathrm{RuO}_{2}$ & 0.00 & 0.01 & 0.00 & 0.01 \\
\hline $\mathrm{SO}_{4}$ & 1.50 & 1.55 & 1.48 & 1.54 \\
\hline $\mathrm{SiO}_{2}$ & 3.38 & 3.22 & 3.35 & 3.19 \\
\hline $\mathrm{ThO}_{2}$ & 0.46 & 0.44 & 0.46 & 0.43 \\
\hline $\mathrm{TiO}_{2}$ & 0.03 & 1.32 & 0.03 & 1.31 \\
\hline $\mathbf{U}_{3} \mathbf{O}_{8}$ & 7.96 & 7.67 & 7.90 & 7.61 \\
\hline $\mathrm{ZnO}$ & 0.08 & 0.08 & 0.08 & 0.07 \\
\hline $\mathrm{ZrO}_{2}$ & 0.28 & 0.27 & 0.27 & 0.27 \\
\hline Cl & 0.00 & 0.60 & 0.00 & 0.60 \\
\hline $\mathbf{F}$ & 0.00 & 0.10 & 0.00 & 0.10 \\
\hline I & 0.00 & 0.02 & 0.00 & 0.02 \\
\hline
\end{tabular}


Table 6. Nominal SB7b May Projections (wt\%, calcined oxides) with $0.84 \mathrm{wt} \% \mathrm{~B}_{2} \mathrm{O}_{3}$.

\begin{tabular}{|c|c|c|c|c|}
\hline & SB7b-May & $\begin{array}{c}\text { SB7b-May- } \\
\text { ARP }\end{array}$ & $\begin{array}{r}\text { SB7b-May } \\
\mathrm{B}_{2} \mathrm{O}_{3}-\mathbf{0 . 8 4}\end{array}$ & $\begin{array}{c}\text { SB7b-May-ARP } \\
\mathrm{B}_{2} \mathrm{O}_{3}-\mathbf{0 . 8 4}\end{array}$ \\
\hline $\mathrm{Al}_{2} \mathrm{O}_{3}$ & 20.22 & 19.38 & 20.05 & 19.22 \\
\hline $\mathrm{B}_{2} \mathrm{O}_{3}$ & 0.00 & 0.00 & 0.84 & 0.84 \\
\hline BaO & 0.11 & 0.11 & 0.11 & 0.11 \\
\hline $\mathrm{CaO}$ & 1.05 & 1.04 & 1.04 & 1.03 \\
\hline $\mathrm{Ce}_{2} \mathrm{O}_{3}$ & 0.13 & 0.13 & 0.13 & 0.13 \\
\hline $\mathrm{Cr}_{2} \mathrm{O}_{3}$ & 0.30 & 0.29 & 0.29 & 0.28 \\
\hline $\mathrm{CuO}$ & 0.06 & 0.06 & 0.06 & 0.06 \\
\hline $\mathrm{Fe}_{2} \mathrm{O}_{3}$ & 27.74 & 26.78 & 27.51 & 26.56 \\
\hline $\mathrm{K}_{2} \mathrm{O}$ & 0.20 & 0.19 & 0.19 & 0.19 \\
\hline $\mathrm{La}_{2} \mathrm{O}_{3}$ & 0.08 & 0.08 & 0.08 & 0.08 \\
\hline MgO & 0.62 & 0.59 & 0.62 & 0.59 \\
\hline $\mathrm{MnO}$ & 5.37 & 5.29 & 5.33 & 5.25 \\
\hline $\mathrm{Na}_{2} \mathrm{O}$ & 25.68 & 26.20 & 25.46 & 25.98 \\
\hline $\mathrm{NiO}$ & 4.49 & 4.31 & 4.45 & 4.27 \\
\hline PbO & 0.04 & 0.05 & 0.04 & 0.05 \\
\hline $\mathrm{RuO}_{2}$ & 0.00 & 0.01 & 0.00 & 0.01 \\
\hline $\mathrm{SO}_{4}$ & 1.49 & 1.55 & 1.48 & 1.54 \\
\hline $\mathrm{SiO}_{2}$ & 3.44 & 3.28 & 3.41 & 3.25 \\
\hline $\mathrm{ThO}_{2}$ & 0.50 & 0.47 & 0.49 & 0.47 \\
\hline $\mathrm{TiO}_{2}$ & 0.03 & 1.32 & 0.03 & 1.31 \\
\hline $\mathbf{U}_{3} \mathbf{O}_{8}$ & 8.10 & 7.80 & 8.03 & 7.73 \\
\hline $\mathrm{ZnO}$ & 0.06 & 0.06 & 0.06 & 0.06 \\
\hline $\mathrm{ZrO}_{2}$ & 0.27 & 0.27 & 0.27 & 0.27 \\
\hline $\mathrm{Cl}$ & 0.00 & 0.60 & 0.00 & 0.60 \\
\hline $\mathbf{F}$ & 0.00 & 0.10 & 0.00 & 0.10 \\
\hline I & 0.00 & 0.02 & 0.00 & 0.02 \\
\hline
\end{tabular}

\section{MAR Assessments with $0.84 \mathrm{wt} \% \mathrm{~B}_{2} \mathrm{O}_{3}$ Based SB7b Projections}

Each of the sludge projections in Table 5 and Table 6 was coupled with Frit 418 and Frit 418-7D (see Table 4) over WLs of 25 to $60 \%$. Glass compositions were calculated for each sludge-fritWL combination and glass properties were predicted. The predicted properties were then compared to their corresponding Product Composition Control System (PCCS) MAR constraints to classify each glass as acceptable (or not). The PCCS models used for this process are identical to those used during the SME acceptability process in DWPF and thus provide a direct comparison with respect to potential SME acceptability decisions once the new SE is introduced into the flowsheet. Within each frit-sludge combination, the WL interval over which all of the glasses are deemed acceptable defines the projected operating window for that system. 
Specific questions that will be addressed in this comparison will be the ability of Frit 418 (without compositional compensation for the new SE) to tolerate additions of $\mathrm{B}_{2} \mathrm{O}_{3}$ up to 0.84 $\mathrm{wt} \%$ in these nominal sludges. In addition, comparisons can be made with respect to the projected operating windows among Frit 418 and Frit 418-7D to evaluate the potential advantages of compositionally altering the frit to account for the increased $\mathrm{B}_{2} \mathrm{O}_{3}$ content of the sludge.

Table 7 summarizes the Nominal Stage MAR assessments for these specific flowsheets. The sludge options have been grouped (shaded) so direct comparisons can be made between the "with and without $\mathrm{B}_{2} \mathrm{O}_{3}$ " additions. For example, the first two shaded rows represent the sludge-only SB7b projections based on an April 2011 SB6 end date without and with the 0.84 wt $\% \mathrm{~B}_{2} \mathrm{O}_{3}$ added (to the sludge), respectively. The projected operating windows when Frit 418 is coupled with these two sludge options is $25-43 \%$ WL with predictions of liquidus temperature $\left(\mathrm{T}_{\mathrm{L}}\right)$ and low viscosity (low $\eta$ ) limiting access to WLs of $44 \%$ or higher. This result suggests that there is no impact of the $0.84 \% \mathrm{~B}_{2} \mathrm{O}_{3}$ addition (in sludge) with respect to the projected operating windows when Frit 418 is used. That is, Frit 418 is robust to the SB7b April sludge-only projection with and without the addition of the next generation solvent stream (up to $0.84 \mathrm{wt} \% \mathrm{~B}_{2} \mathrm{O}_{3}$ in sludge).

Table 7. Projected Operating Windows for the SB7b Projections with and without the 0.84 wt $\% \mathrm{~B}_{2} \mathrm{O}_{3}$ Addition with Frit 418 and Frit 418-7D.

\begin{tabular}{||l|c|c||}
\hline Sludge Option & Frit 418 & Frit 418-7D \\
\hline SB7b April & $25-43$ & $25-43$ \\
& $\mathrm{~T}_{\mathrm{L}} /$ low $\eta$ & $\mathrm{T}_{\mathrm{L}}$ \\
\hline SB7b April $\mathbf{B}_{\mathbf{2}} \mathbf{O}_{\mathbf{3}}: \mathbf{0 . 8 4}$ & $25-43$ & $25-43$ \\
& $\mathrm{~T}_{\mathrm{L}} /$ low $\eta$ & $\mathrm{T}_{\mathrm{L}}$ \\
\hline SB7b April ARP & $25-43$ & $25-43$ \\
& low $\eta$ & low $\eta$ \\
\hline SB7b April ARP $\mathbf{B}_{\mathbf{2}} \mathbf{O}_{\mathbf{3}} \mathbf{0 . 8 4}$ & $25-42$ & $25-43$ \\
& low $\eta$ & low $\eta$ \\
\hline SB7b May & $25-43$ & $25-43$ \\
& $\mathrm{~T}_{\mathrm{L}} /$ low $\eta$ & $\mathrm{T}_{\mathrm{L}}$ \\
\hline SB7b May $\mathbf{B}_{2} \mathbf{O}_{\mathbf{3}}: \mathbf{0 . 8 4}$ & $25-43$ & $25-43$ \\
& $\mathrm{~T}_{\mathrm{L}} /$ low $\eta$ & $\mathrm{T}_{\mathrm{L}}$ \\
\hline SB7b May ARP & $25-42$ & $25-43$ \\
& low $\eta$ & low $\eta$ \\
\hline SB7b May ARP $\mathbf{B}_{\mathbf{2}} \mathbf{O}_{\mathbf{3}} \mathbf{0 . 8 4}$ & $25-42$ & $25-43$ \\
& low $\eta$ & low $\eta$ \\
\hline \hline
\end{tabular}

When ARP is added to the April SB7b-Frit 418 system (without additions of $\mathrm{B}_{2} \mathrm{O}_{3}$ ), the projected operating window remains $25-43 \%$ WL with predictions of low $\eta$ limiting access to higher WLs. When the boric acid stream is added to this coupled operations flowsheet, the projected operating window does decrease slightly to $25-42 \%$ WL. However, this is not viewed as a significant or practical impact to DWPF given a nominal contractual WL of $36 \%$ is targeted for SB $7 \mathrm{~b}$. In fact, addition of the new SE at $0.84 \mathrm{wt} \%$ to the coupled flowsheet is the only case where a reduction of the projected operating window occurs for the April projections. 
A review of the projected operating windows for the May SB7b flowsheet options suggest that the use of Frit 418 results in a similar trend with respect to accessible WL intervals. All of the sludge-only and coupled flowsheets have projected operating windows of 25 to 42 or $43 \% \mathrm{WL}$ regardless of the presence of the $0.84 \mathrm{wt} \% \mathrm{~B}_{2} \mathrm{O}_{3}$ in sludge. These results show the predicted robustness of Frit 418 not only to the SB6 end date (April or May 2011) and sludge-only versus coupled operations (ARP), but also the potential to tolerate $\mathrm{B}_{2} \mathrm{O}_{3}$ additions to the sludge at the $0.84 \mathrm{wt} \%$ level.

As previously mentioned, no compositional adjustments were made to Frit 418 to account for the addition of the $0.84 \mathrm{wt} \% \mathrm{~B}_{2} \mathrm{O}_{3}$ from the new solvent. Frit 418-7D was compositionally adjusted via a reduction in the $\mathrm{B}_{2} \mathrm{O}_{3}$ content of $0.56 \mathrm{wt} \%$ to account for the new SE. A review of the projected operating windows for Frit 418-7D shows no difference in the WL interval over which any of the flowsheets could be processed. That is, all of the projected operating windows are 25$43 \% \mathrm{WL}$ regardless of the flowsheet option presented in Table 7 . Therefore, adjustments can be made to the frit (if required) to account for the relatively small addition of $\mathrm{B}_{2} \mathrm{O}_{3}$ to the SRAT from the new SE based on the current $0.01 \mathrm{M}$ baseline flowsheet and calculations performed by Stone [2010].

Based on the 1-20-11 SB7b projections and the results of the MAR assessments, Frit 418 and Frit 418-7D are robust to the implementation of the $0.01 \mathrm{M}$ boric acid SE into the SB7b flowsheet (sludge-only or ARP-added). These results suggest that even if SE is not transferred to the SRAT, there would not be a need to add boric acid (from a trim tank) to compositionally compensate for the absence of the boron-containing SE in either a sludge-only or ARP-added SB7b flowsheet. Although there is no driver for a trim tank with respect to the MAR assessments, one also needs to consider the impact of both frits on the final $\mathrm{B}_{2} \mathrm{O}_{3}$ content in glass. That is, if Frit 418-7d is used to process SB7b and there is no addition of SE into the flowsheet, at $40 \% \mathrm{WL}$, the glass being processed would have a nominal $\mathrm{B}_{2} \mathrm{O}_{3}$ content of $4.46 \mathrm{wt} \%$. If these lower $\mathrm{B}_{2} \mathrm{O}_{3}$ concentrations were a concern, then use of Frit 418 would eliminate that issue. That is, if Frit 418 is used for SB7b processing and the SE is not added, the $\mathrm{B}_{2} \mathrm{O}_{3}$ content of the glass would be $4.8 \mathrm{wt} \%$. In fact, if $\mathrm{B}_{2} \mathrm{O}_{3}$ content in the final glass is of concern, new frits with higher $\mathrm{B}_{2} \mathrm{O}_{3}$ concentrations (including a slightly higher $\mathrm{B}_{2} \mathrm{O}_{3}$ content version of Frit 418 (e.g., $8.5 \mathrm{wt} \%$ )) could be developed or the current specifications $\left(\mathrm{B}_{2} \mathrm{O}_{3}: 8 \pm 0.65 \mathrm{wt} \%\right)$ could be altered to avoid the lower $\mathrm{B}_{2} \mathrm{O}_{3}$ concentrations.

\section{MAR Assessment Results with $>0.84 \mathrm{wt} \% \mathrm{~B}_{2} \mathrm{O}_{3}$ Additions to SB7b Projections}

Given that the results of the MAR assessment with the nominal $0.84 \mathrm{wt} \% \mathrm{~B}_{2} \mathrm{O}_{3}$ addition indicated that the introduction of the boric acid to the flowsheet had no (or very little) impact on the projected operating windows (for either Frit 418 or Frit 418-7D), higher concentrations of $\mathrm{B}_{2} \mathrm{O}_{3}$ were added to the baseline flowsheets to evaluate their potential impact. More specifically, 0.9, 1.0, and $2.0 \mathrm{wt} \% \mathrm{~B}_{2} \mathrm{O}_{3}$ were added to the four SB7b baseline flowsheets (from Table 1) to assess the impact of a higher boric acid molarity added to the SRAT. For example, consider the addition of $2.0 \mathrm{wt} \% \mathrm{~B}_{2} \mathrm{O}_{3}$ to the sludge. At $40 \% \mathrm{WL}$, this would provide $0.8 \mathrm{wt} \% \mathrm{~B}_{2} \mathrm{O}_{3}$ to the glass. If a $\mathrm{B}_{2} \mathrm{O}_{3}$ content in glass at $40 \% \mathrm{WL}$ was maintained at $4.8 \mathrm{wt} \%$ (via the use of Frit 418 ), the $\mathrm{B}_{2} \mathrm{O}_{3}$ content of a compositionally altered Frit 418 would be $6.67 \mathrm{wt} \%$. This $\left(6.67 \mathrm{wt} \% \mathrm{~B}_{2} \mathrm{O}_{3}\right.$ in frit $)$ is approximately $83 \%$ of the nominal Frit $418 \mathrm{~B}_{2} \mathrm{O}_{3}$ content. 
Under these conditions, $0.8 \mathrm{wt} \%(2 \mathrm{wt} \% * 0.4 \mathrm{WL})$ of the $4.8 \mathrm{wt} \% \mathrm{~B}_{2} \mathrm{O}_{3}$ content in glass would result from the sludge contribution while the $4.0 \mathrm{wt} \%$ of the $\mathrm{B}_{2} \mathrm{O}_{3}$ in glass would be contributed by the frit (or $6.67 \% * 0.6$ ). Therefore to maintain a $4.8 \% \mathrm{~B}_{2} \mathrm{O}_{3}$ content in glass at $40 \% \mathrm{WL}$, the sludge could contain approximately $16.7 \%$ of Frit 418 's $\mathrm{B}_{2} \mathrm{O}_{3}$. Using the calculations by Stone [2010] as a guide, this could approximate the following conditions: (a) up to 55,000 liters of SE added per SRAT batch for a $0.1 \mathrm{M}$ boric acid flowsheet, (b) up to approximately 25,000 liters of SE per SRAT batch for a $0.25 \mathrm{M}$ boric acid flowsheet, or (c) up to approximately 10,000 liters of SE per SRAT batch for a $0.5 \mathrm{M}$ boric acid flowsheet. Again, these conditions are outside the concentrations anticipated for the $0.01 \mathrm{M}$ boric acid baseline flowsheet.

As previously mentioned, to target the same $\mathrm{B}_{2} \mathrm{O}_{3}$ content in glass at $40 \%$ WL for these three higher $\mathrm{B}_{2} \mathrm{O}_{3}$ sludge levels, Frit 418 should be compositionally altered to account for the incoming $\mathrm{B}_{2} \mathrm{O}_{3}$ from the SE. However, given the robustness of Frit 418 and Frit 418-7D to the maximum $\mathrm{B}_{2} \mathrm{O}_{3}$ contribution of the $0.01 \mathrm{M}$ flowsheet, the authors wanted to see if a higher boric acid molarity and/or SE volume added to the SRAT could be tolerated with either frit. If so, the system could be more robust than initially demonstrated through the $0.84 \mathrm{wt} \%$ concentrations. Although not bounding all of the scenarios outlined by Stone [2010], addition of up to $2 \mathrm{wt} \%$ $\mathrm{B}_{2} \mathrm{O}_{3}$ to the sludge will provide insight into the robustness of the Frit 418 or Frit 418-7D to higher concentrations.

Table 8, Table 9, and Table 10 summarize the nominal sludge compositions with the addition of $0.9,1.0$, and $2.0 \mathrm{wt} \% \mathrm{~B}_{2} \mathrm{O}_{3}$, respectively to the baseline SB7b flowsheets (April/May and sludgeonly/ARP). 
Table 8. Nominal SB7b Projections (wt\%, calcined oxides) with $0.9 \mathrm{wt} \% \mathrm{~B}_{2} \mathrm{O}_{3}$ Addition.

\begin{tabular}{|c|c|c|c|c|}
\hline & $\begin{array}{c}\text { SB7b-April } \\
\mathrm{B}_{2} \mathrm{O}_{3}-\mathbf{0 . 9 0} \\
\end{array}$ & $\begin{array}{l}\text { SB7b-May } \\
\mathrm{B}_{2} \mathrm{O}_{3}-\mathbf{0 . 9 0}\end{array}$ & $\begin{array}{c}\text { SB7b-April-ARP } \\
\mathrm{B}_{2} \mathrm{O}_{3}-0.90 \\
\end{array}$ & $\begin{array}{c}\text { SB7b-May-ARP } \\
\mathbf{B}_{2} \mathbf{O}_{3}-0.90 \\
\end{array}$ \\
\hline $\mathbf{A l}_{2} \mathbf{O}_{3}$ & 20.33 & 20.03 & 19.49 & 19.21 \\
\hline $\mathbf{B}_{2} \mathbf{O}_{3}$ & 0.90 & 0.90 & 0.90 & 0.90 \\
\hline BaO & 0.11 & 0.11 & 0.11 & 0.11 \\
\hline $\mathrm{CaO}$ & 1.07 & 1.04 & 1.06 & 1.03 \\
\hline $\mathrm{Ce}_{2} \mathrm{O}_{3}$ & 0.13 & 0.13 & 0.13 & 0.13 \\
\hline $\mathrm{Cr}_{2} \mathrm{O}_{3}$ & 0.30 & 0.29 & 0.28 & 0.28 \\
\hline $\mathrm{CuO}$ & 0.06 & 0.06 & 0.06 & 0.06 \\
\hline $\mathrm{Fe}_{2} \mathrm{O}_{3}$ & 27.42 & 27.49 & 26.47 & 26.54 \\
\hline $\mathrm{K}_{2} \mathrm{O}$ & 0.18 & 0.19 & 0.18 & 0.19 \\
\hline $\mathrm{La}_{2} \mathrm{O}_{3}$ & 0.08 & 0.08 & 0.08 & 0.08 \\
\hline MgO & 0.62 & 0.62 & 0.59 & 0.59 \\
\hline $\mathrm{MnO}$ & 5.38 & 5.32 & 5.30 & 5.25 \\
\hline $\mathrm{Na}_{2} \mathrm{O}$ & 25.42 & 25.45 & 25.94 & 25.97 \\
\hline $\mathrm{NiO}$ & 4.39 & 4.45 & 4.21 & 4.27 \\
\hline PbO & 0.04 & 0.04 & 0.05 & 0.05 \\
\hline $\mathrm{RuO}_{2}$ & 0.00 & 0.00 & 0.01 & 0.01 \\
\hline $\mathrm{SO}_{4}$ & 1.48 & 1.48 & 1.54 & 1.54 \\
\hline $\mathrm{SiO}_{2}$ & 3.35 & 3.41 & 3.19 & 3.25 \\
\hline $\mathrm{ThO}_{2}$ & 0.46 & 0.49 & 0.43 & 0.47 \\
\hline $\mathrm{TiO}_{2}$ & 0.03 & 0.03 & 1.31 & 1.31 \\
\hline $\mathrm{U}_{3} \mathrm{O}_{8}$ & 7.89 & 8.02 & 7.60 & 7.73 \\
\hline $\mathrm{ZnO}$ & 0.08 & 0.06 & 0.07 & 0.06 \\
\hline $\mathrm{ZrO}_{2}$ & 0.27 & 0.27 & 0.27 & 0.27 \\
\hline $\mathrm{Cl}$ & 0.00 & 0.00 & 0.60 & 0.60 \\
\hline $\mathbf{F}$ & 0.00 & 0.00 & 0.10 & 0.10 \\
\hline I & 0.00 & 0.00 & 0.02 & 0.02 \\
\hline
\end{tabular}


Table 9. Nominal SB7b Projections (wt \%, calcined oxides) with $1.0 \mathrm{wt} \% \mathrm{~B}_{2} \mathrm{O}_{3}$ Additions.

\begin{tabular}{|c|c|c|c|c|}
\hline & $\begin{array}{c}\text { SB7b-April } \\
\mathrm{B}_{2} \mathrm{O}_{3}-1.0 \\
\end{array}$ & $\begin{array}{c}\text { SB7b-May } \\
\mathrm{B}_{2} \mathrm{O}_{3}-1.0 \\
\end{array}$ & $\begin{array}{c}\text { SB7b-April-ARP } \\
\text { B }_{2} \mathrm{O}_{3}-1.0 \\
\end{array}$ & $\begin{array}{c}\text { SB7b-May-ARP } \\
\text { B }_{2} \mathbf{O}_{3}-1.0 \\
\end{array}$ \\
\hline $\mathbf{A l}_{2} \mathbf{O}_{3}$ & 20.31 & 20.01 & 19.47 & 19.19 \\
\hline $\mathrm{B}_{2} \mathrm{O}_{3}$ & 1.00 & 1.00 & 1.00 & 1.00 \\
\hline $\mathrm{BaO}$ & 0.11 & 0.11 & 0.11 & 0.11 \\
\hline $\mathrm{CaO}$ & 1.07 & 1.04 & 1.06 & 1.03 \\
\hline $\mathrm{Ce}_{2} \mathrm{O}_{3}$ & 0.13 & 0.13 & 0.13 & 0.13 \\
\hline $\mathrm{Cr}_{2} \mathrm{O}_{3}$ & 0.29 & 0.29 & 0.28 & 0.28 \\
\hline $\mathrm{CuO}$ & 0.06 & 0.06 & 0.06 & 0.06 \\
\hline $\mathrm{Fe}_{2} \mathrm{O}_{3}$ & 27.39 & 27.47 & 26.44 & 26.51 \\
\hline $\mathrm{K}_{2} \mathrm{O}$ & 0.18 & 0.19 & 0.18 & 0.19 \\
\hline $\mathrm{La}_{2} \mathrm{O}_{3}$ & 0.08 & 0.08 & 0.08 & 0.08 \\
\hline MgO & 0.62 & 0.62 & 0.59 & 0.59 \\
\hline MnO & 5.38 & 5.32 & 5.30 & 5.24 \\
\hline $\mathrm{Na}_{2} \mathrm{O}$ & 25.39 & 25.42 & 25.91 & 25.94 \\
\hline $\mathrm{NiO}$ & 4.39 & 4.45 & 4.21 & 4.26 \\
\hline PbO & 0.04 & 0.04 & 0.05 & 0.05 \\
\hline $\mathrm{RuO}_{2}$ & 0.00 & 0.00 & 0.01 & 0.01 \\
\hline $\mathrm{SO}_{4}$ & 1.48 & 1.48 & 1.54 & 1.54 \\
\hline $\mathrm{SiO}_{2}$ & 3.34 & 3.40 & 3.19 & 3.24 \\
\hline $\mathrm{ThO}_{2}$ & 0.46 & 0.49 & 0.43 & 0.46 \\
\hline $\mathrm{TiO}_{2}$ & 0.03 & 0.03 & 1.31 & 1.31 \\
\hline $\mathbf{U}_{3} \mathbf{O}_{8}$ & 7.88 & 8.01 & 7.60 & 7.72 \\
\hline $\mathrm{ZnO}$ & 0.08 & 0.06 & 0.07 & 0.06 \\
\hline $\mathrm{ZrO}_{2}$ & 0.27 & 0.27 & 0.27 & 0.27 \\
\hline $\mathrm{Cl}$ & 0.00 & 0.00 & 0.60 & 0.60 \\
\hline $\mathbf{F}$ & 0.00 & 0.00 & 0.10 & 0.10 \\
\hline I & 0.00 & 0.00 & 0.02 & 0.02 \\
\hline
\end{tabular}


Table 10. Nominal SB7b Projections (wt\%, calcined oxides) with $2.0 \mathrm{wt} \% \mathrm{~B}_{2} \mathrm{O}_{3}$ Additions.

\begin{tabular}{|c|c|c|c|c|}
\hline & $\begin{array}{c}\text { SB7b-April } \\
\mathbf{B}_{2} \mathbf{O}_{3}-2.0 \\
\end{array}$ & $\begin{array}{l}\text { SB7b-May } \\
\mathbf{B}_{2} \mathbf{O}_{3}-2.0 \\
\end{array}$ & $\begin{array}{c}\text { SB7b-April-ARP } \\
\text { B }_{2} \mathbf{O}_{3}-2.0 \\
\end{array}$ & $\begin{array}{c}\text { SB7b-May-ARP } \\
\mathbf{B}_{2} \mathbf{O}_{3}-2.0 \\
\end{array}$ \\
\hline $\mathrm{Al}_{2} \mathrm{O}_{3}$ & 20.10 & 19.81 & 19.27 & 19.00 \\
\hline $\mathrm{B}_{2} \mathrm{O}_{3}$ & 2.00 & 2.00 & 2.00 & 2.00 \\
\hline BaO & 0.11 & 0.11 & 0.11 & 0.11 \\
\hline $\mathrm{CaO}$ & 1.06 & 1.03 & 1.05 & 1.02 \\
\hline $\mathrm{Ce}_{2} \mathrm{O}_{3}$ & 0.13 & 0.13 & 0.13 & 0.13 \\
\hline $\mathrm{Cr}_{2} \mathrm{O}_{3}$ & 0.29 & 0.29 & 0.28 & 0.28 \\
\hline $\mathrm{CuO}$ & 0.06 & 0.06 & 0.06 & 0.06 \\
\hline $\mathrm{Fe}_{2} \mathrm{O}_{3}$ & 27.11 & 27.19 & 26.17 & 26.24 \\
\hline $\mathbf{K}_{2} \mathbf{O}$ & 0.18 & 0.19 & 0.18 & 0.19 \\
\hline $\mathrm{La}_{2} \mathrm{O}_{3}$ & 0.08 & 0.08 & 0.08 & 0.08 \\
\hline MgO & 0.61 & 0.61 & 0.58 & 0.58 \\
\hline MnO & 5.32 & 5.26 & 5.24 & 5.19 \\
\hline $\mathrm{Na}_{2} \mathrm{O}$ & 25.13 & 25.16 & 25.65 & 25.68 \\
\hline NiO & 4.34 & 4.40 & 4.16 & 4.22 \\
\hline PbO & 0.04 & 0.04 & 0.05 & 0.05 \\
\hline $\mathrm{RuO}_{2}$ & 0.00 & 0.00 & 0.01 & 0.01 \\
\hline $\mathrm{SO}_{4}$ & 1.47 & 1.46 & 1.52 & 1.52 \\
\hline $\mathrm{SiO}_{2}$ & 3.31 & 3.37 & 3.16 & 3.21 \\
\hline $\mathrm{ThO}_{2}$ & 0.45 & 0.49 & 0.43 & 0.46 \\
\hline $\mathrm{TiO}_{2}$ & 0.03 & 0.03 & 1.30 & 1.30 \\
\hline $\mathbf{U}_{3} \mathbf{O}_{8}$ & 7.80 & 7.93 & 7.52 & 7.64 \\
\hline $\mathrm{ZnO}$ & 0.07 & 0.06 & 0.07 & 0.06 \\
\hline $\mathrm{ZrO}_{2}$ & 0.27 & 0.27 & 0.26 & 0.26 \\
\hline $\mathrm{Cl}$ & 0.00 & 0.00 & 0.59 & 0.59 \\
\hline $\mathbf{F}$ & 0.00 & 0.00 & 0.10 & 0.10 \\
\hline I & 0.00 & 0.00 & 0.02 & 0.02 \\
\hline
\end{tabular}


Table 11 and Table 12 summarize the projected operating windows for the $\mathrm{B}_{2} \mathrm{O}_{3}$ additions of 0.9 , 1.0, and $2.0 \mathrm{wt} \%$ to both the April and May SB7b projections, respectively. Also shown in these tables are the nominal sludge-only and ARP April and May MAR assessment results (as discussed in the previous section) which serve as a baseline for comparison.

Table 11. Projected Operating windows for the April SB7b Projections with $\mathrm{B}_{2} \mathrm{O}_{3}$ Additions of 0.84, 0.9, 1.0, and $2.0 \mathrm{wt} \%$.

\begin{tabular}{|c|c|c|}
\hline Sludge Option & Frit 418 & Frit 418-7D \\
\hline SB7b April & $\begin{array}{c}25-43 \\
T_{L} / \text { low } \eta\end{array}$ & $\begin{array}{c}25-43 \\
T_{L}\end{array}$ \\
\hline SB7b April $\mathrm{B}_{2} \mathrm{O}_{3}: 0.84$ & $\begin{array}{c}25-43 \\
\mathrm{~T}_{\mathrm{L}} / \text { low } \eta\end{array}$ & $\begin{array}{c}25-43 \\
T_{L}\end{array}$ \\
\hline SB7b April $\mathrm{B}_{2} \mathrm{O}_{3}: 0.90$ & $\begin{array}{c}25-43 \\
\mathrm{~T}_{\mathrm{L}} / \text { low } \eta\end{array}$ & $\begin{array}{c}25-43 \\
T_{L}\end{array}$ \\
\hline SB7b April $\mathrm{B}_{2} \mathrm{O}_{3}: 1.0$ & $\begin{array}{c}25-43 \\
\mathrm{~T}_{\mathrm{L}} / \text { low } \eta\end{array}$ & $\begin{array}{c}25-43 \\
T_{L}\end{array}$ \\
\hline SB7b April $\mathrm{B}_{2} \mathrm{O}_{3}: 2.0$ & $\begin{array}{c}25-43 \\
\mathrm{~T}_{\mathrm{L}} / \text { low } \eta\end{array}$ & $\begin{array}{c}25-43 \\
T_{L}\end{array}$ \\
\hline SB7b April ARP & $\begin{array}{l}25-43 \\
\text { low } \eta\end{array}$ & $\begin{array}{l}25-43 \\
\text { low } \eta\end{array}$ \\
\hline SB7b April ARP $\mathrm{B}_{2} \mathrm{O}_{3}: 0.84$ & $\begin{array}{l}25-42 \\
\text { low } \eta\end{array}$ & $\begin{array}{l}25-43 \\
\text { low } \eta\end{array}$ \\
\hline SB7b April ARP $\mathrm{B}_{2} \mathrm{O}_{3}: 0.90$ & $\begin{array}{l}25-42 \\
\text { low } \eta\end{array}$ & $\begin{array}{l}25-43 \\
\text { low } \eta\end{array}$ \\
\hline SB7b April ARP $B_{2} O_{3}: 1.0$ & $\begin{array}{l}25-42 \\
\text { low } \eta\end{array}$ & $\begin{array}{l}25-43 \\
\text { low } \eta\end{array}$ \\
\hline SB7b April ARP $\mathrm{B}_{2} \mathrm{O}_{3}: 2.0$ & $\begin{array}{l}25-42 \\
\text { low } \eta\end{array}$ & $\begin{array}{l}25-43 \\
\text { low } \eta\end{array}$ \\
\hline
\end{tabular}

A review of the projected operating windows for the April projections with Frit 418 and Frit 418 7D (Table 11) indicates that both frits are robust to $\mathrm{B}_{2} \mathrm{O}_{3}$ contents in sludge up to $2.0 \mathrm{wt} \%$. As with the results of the $0.84 \mathrm{wt} \% \mathrm{~B}_{2} \mathrm{O}_{3}$ additions, the only difference observed between Frit 418 and Frit 418-7D is a slight reduction (1\% point) in WL for the ARP-added sludges with Frit 418. This is not considered a practical limitation given the nominal contractual WL of $36 \%$ for SB7b. However, this does demonstrate that $\mathrm{B}_{2} \mathrm{O}_{3}$-deficient frits can be developed to offset the introduction of $\mathrm{B}_{2} \mathrm{O}_{3}$ from the $\mathrm{SE}$ into the SRAT product (i.e., no changes in the projected operating window for Frit 418-7D).

The same general trends are shown in Table 12 for the May SB7b projections. Although both frits demonstrate the same high degree of robustness as shown for the April projections, Frit 4187D appears to be more tolerant of the additions of ARP and $\mathrm{B}_{2} \mathrm{O}_{3}$ from the new SE. Again, these differences are not considered practical as all of the operating windows provide access to either 42 or $43 \%$ WL. 
Table 12. Projected Operating windows for the May SB7b Projections with $\mathrm{B}_{2} \mathrm{O}_{3}$ Additions of $0.84,0.9,1.0$, and $2.0 \mathrm{wt} \%$.

\begin{tabular}{|c|c|c|}
\hline Sludge Option & Frit 418 & Frit 418-7D \\
\hline SB7b May & $\begin{array}{c}25-43 \\
\mathrm{~T}_{\mathrm{L}} / \text { low } \eta\end{array}$ & $\begin{array}{c}25-43 \\
T_{L} \\
\end{array}$ \\
\hline SB7b May $\mathrm{B}_{2} \mathrm{O}_{3}: 0.84$ & $\begin{array}{c}25-43 \\
\mathrm{~T}_{\mathrm{L}} / \text { low } \eta\end{array}$ & $\begin{array}{c}25-43 \\
\mathrm{~T}_{\mathrm{L}}\end{array}$ \\
\hline SB7b May $\mathrm{B}_{2} \mathrm{O}_{3}: 0.90$ & $\begin{array}{c}25-43 \\
\mathrm{~T}_{\mathrm{L}} / \text { low } \eta\end{array}$ & $\begin{array}{c}25-43 \\
T_{L}\end{array}$ \\
\hline SB7b May $B_{2} O_{3}: 1.0$ & $\begin{array}{c}25-43 \\
\mathrm{~T}_{\mathrm{L}} / \text { low } \eta\end{array}$ & $\begin{array}{c}25-43 \\
\mathrm{~T}_{\mathrm{L}} \\
\end{array}$ \\
\hline SB7b May $\mathrm{B}_{2} \mathrm{O}_{3}: 2.0$ & $\begin{array}{c}25-43 \\
T_{L} / \text { low } \eta\end{array}$ & $\begin{array}{c}25-43 \\
T_{L} / \text { low } \eta\end{array}$ \\
\hline SB7b May ARP & $\begin{array}{l}25-42 \\
\text { low } \eta\end{array}$ & $\begin{array}{l}25-43 \\
\text { low } \eta\end{array}$ \\
\hline SB7b May ARP $B_{2} O_{3}: 0.84$ & $\begin{array}{l}25-42 \\
\text { low } \eta\end{array}$ & $\begin{array}{l}25-43 \\
\text { low } \eta\end{array}$ \\
\hline SB7b May ARP $\mathrm{B}_{2} \mathrm{O}_{3}: 0.90$ & $\begin{array}{l}25-42 \\
\text { low } \eta\end{array}$ & $\begin{array}{l}25-43 \\
\text { low } \eta\end{array}$ \\
\hline SB7b May ARP $\mathrm{B}_{2} \mathrm{O}_{3}: 1.0$ & $\begin{array}{l}25-42 \\
\text { low } \eta\end{array}$ & $\begin{array}{l}25-43 \\
\text { low } \eta\end{array}$ \\
\hline SB7b May ARP $\mathrm{B}_{2} \mathrm{O}_{3}: 2.0$ & $\begin{array}{l}25-42 \\
\text { low } \eta\end{array}$ & $\begin{array}{l}25-43 \\
\text { low } \eta\end{array}$ \\
\hline
\end{tabular}

Based on information presented in Table 11 and Table 12, there is very little, if any, impact of the $0.01 \mathrm{M}$ boric acid flowsheet on the projected operating windows for the April or May SB7b projections with up to $2 \mathrm{wt} \% \mathrm{~B}_{2} \mathrm{O}_{3}$ additions when Frit 418 or Frit $418-7 \mathrm{D}$ are used. There are slight differences between Frit 418 and Frit 418-7D (which was compositionally altered to account for the maximum boric acid addition for the $0.01 \mathrm{M}$ flowsheet as defined by Stone [2010]) with respect to the projected operating windows. The projected operating windows for Frit 418-7D were constant (e.g., 25-43\% WL) regardless of the flowsheet option. With Frit 418, there was a slight reduction (of 1 percentage point in WL) in the projected operating windows associated with the ARP-added flowsheets although this is not considered to be a significant practical impact. It should be reiterated that the $2 \mathrm{wt} \% \mathrm{~B}_{2} \mathrm{O}_{3}$ addition exceeds the maximum concentration of $0.84 \mathrm{wt} \%$ was defined by Stone [2010] based on 70,000 liters of SE being added to the SRAT for the baseline $0.01 \mathrm{M}$ boric acid flowsheet. The MAR assessments suggest that that there is no need to add a $\mathrm{B}_{2} \mathrm{O}_{3}$ trim tank into the SB7b flowsheet even with these higher $\mathrm{B}_{2} \mathrm{O}_{3}$ concentration sludges (e.g., an increase relative to the $0.01 \mathrm{M}$ baseline flowsheet). However, a trim tank would be required if the $\mathrm{B}_{2} \mathrm{O}_{3}$ content from the $\mathrm{SE}$ become sufficiently high and no SE was added to the SRAT. Under this situation (again this example is outside the current baseline flowsheet), trimming the SRAT (or SME) with $\mathrm{B}_{2} \mathrm{O}_{3}$ would be required to maintain the targeted $\mathrm{B}_{2} \mathrm{O}_{3}$ concentration in the glass assuming the frit composition has been lowered to account for in incoming SE. 


\section{Volatilization}

Stone [2010] identified volatilization as a potential concern with the introduction of boric acid into the DWPF flowsheet. The technical questions with the introduction of a boron-laden liquid and volatilization evolve around the potential partitioning of boron from the strip effluent into the off-gas (i.e., volatilization or entrainment) once introduced into the melter. With respect to volatility, DWPF has demonstrated through pour stream analysis that volatility of $\mathrm{B}_{2} \mathrm{O}_{3}$ is not an issue when a pre-fabricated (solid) frit containing the only source of $\mathrm{B}_{2} \mathrm{O}_{3}$ is used. Given the SE will introduce a liquid-based boron source into the melter, will boron be more susceptible to volatilization given it is in a liquid phase (i.e., SE) instead of being chemically bonded in the prefabricated frit? If so, what are the downstream impacts to either process related criteria (viscosity or liquidus temperature) or product performance criteria such as durability? If boron volatility does occur in the melter, the critical process and product performance properties could be affected after SME acceptability decisions. This is a situation which must be avoided as it ultimately could influence waste form affecting constraints such as durability.

In addition, not only could volatilization in the melter become an issue but during the SME acceptability process, SME samples are vitrified in a small laboratory crucible using a resistance heated furnace. If boron volatility occurs during that process, the composition of the SME product (from which decisions regarding acceptability are based) could be "biased low" with respect to boron. It should be noted that even if boron volatility were not an issue during vitrification of the SME product, analytical measurements could lead to a low measurement of $\mathrm{B}_{2} \mathrm{O}_{3}$. Therefore, the question becomes how sensitive would the SME acceptability process be to $\mathrm{B}_{2} \mathrm{O}_{3}$ retention or volatility? Or what impact would boron volatility have on predicted glass properties? Obviously, the issues associated with boron volatility become more critical as the contribution of the $\mathrm{B}_{2} \mathrm{O}_{3}$ content in the glass from the $\mathrm{SE}$ increase. For example, assuming boron volatility does occur, the impact of SME acceptability decisions and actual glass properties within the melter become more of an issue at the higher boric acid molarity flowsheets or higher volumes of $\mathrm{SE}$ added to the SRAT. Under conditions where the SE contributes significant portions of $\mathrm{B}_{2} \mathrm{O}_{3}$ to the overall flowsheet, having to account for boron volatility to maintain a "constant" glass composition would be almost impossible especially if boron volatility was dependent on the operational mode of the melter (i.e., feed rates, bubbling rates, melt temperature, etc). This latter situation could set up an almost impossible position to account for a variable volatilization rate through upstream additions of boric acid to maintain acceptable glass properties during both the SME acceptability process as well as within the melter.

To support the possible impact of $\mathrm{B}_{2} \mathrm{O}_{3}$ volatilization on SME acceptability decision and predicted glass properties, SRNL performed a paper study assessment using standard Measurement Acceptability Region (MAR) protocols to evaluate the impact of boron volatility on possible SME acceptability decision and various predicted properties. 


\section{MAR Assessment: Impact of $\mathrm{B}_{2} \mathrm{O}_{3}$ Volatility on Predicted Properties and SME Acceptability Decisions}

With respect to the MAR assessments, a paper study was performed to determine whether the current process control models are sensitive to the anticipated changes in $\mathrm{B}_{2} \mathrm{O}_{3}$ content of the glass when the changes are the result of volatility during vitrification of the SME product or during melter operations. Initial MAR assessments evaluated boron concentration changes assuming $0 \%$ (full retention) to $100 \%$ boron volatility for the baseline $0.01 \mathrm{M}$ boric acid flowsheet and the May SB7b projections. More specifically, the nominal SB7b May projections (sludgeonly and ARP) with $0.84 \mathrm{wt} \% \mathrm{~B}_{2} \mathrm{O}_{3}$ were used to support this assessment (see Table 6). These sludge compositions were coupled with Frit 418 at $40 \%$ WL resulting in four glass compositions assuming no $\mathrm{B}_{2} \mathrm{O}_{3}$ volatilization. Four additional glass compositions were computed assuming $100 \%$ volatilization of the $\mathrm{B}_{2} \mathrm{O}_{3}$ content being contributed from the sludge (or SE) occurred. Predicted glass properties were then computed through the use of the current PCCS models supporting SME acceptability and ultimately compared to PCCS constraints to determine acceptability. The predicted properties and MAR acceptability classifications are shown in Table 13.

Table 13. Predicted Properties and MAR Status for $100 \%$ Retention and $100 \%$ Volatility of $\mathrm{B}_{2} \mathrm{O}_{3}$ from the SE at $40 \% \mathrm{WL}$.

\begin{tabular}{||c|c|c|c|c|c||}
\hline Sludge Type & $\begin{array}{c}\text { NL }[\mathbf{B}] \\
(\mathbf{g} / \mathbf{L})\end{array}$ & $\begin{array}{c}\mathbf{T}_{\mathbf{L}} \\
\left({ }^{\circ} \mathbf{C}\right)\end{array}$ & $\begin{array}{c}\text { Viscosity } \\
(\text { Poise) }\end{array}$ & $\begin{array}{c}\text { Nepheline } \\
\text { Value }\end{array}$ & $\begin{array}{c}\text { MAR } \\
\text { Status }\end{array}$ \\
\hline Sludge-Only & & & & & \\
\hline SB7b-May 100\% Retention & 1.419 & 973.98 & 31.40 & 0.670 & - \\
\hline SB7b-May 100\% Volatility & 1.419 & 973.98 & 31.40 & 0.670 & - \\
\hline SB7b-May $\mathrm{B}_{2} \mathrm{O}_{3}-0.84100 \%$ Retention & 1.420 & 971.81 & 31.03 & 0.671 & - \\
\hline SB7b-May $\mathrm{B}_{2} \mathrm{O}_{3}-0.84100 \%$ Volatility & 1.412 & 971.81 & 31.82 & 0.671 & - \\
\hline ARP & & & & & \\
\hline SB7b-May ARP100\% Retention & 1.555 & 954.35 & 29.94 & 0.671 & - \\
\hline SB7b-May $\mathrm{ARP}_{100 \% \text { Volatility }}$ & 1.555 & 954.35 & 29.94 & 0.671 & - \\
\hline SB7b-May ARP $\mathrm{B}_{2} \mathrm{O}_{3}-84100 \%$ Retention & 1.555 & 952.26 & 29.59 & 0.672 & - \\
\hline SB7b-May-ARP $\mathrm{B}_{2} \mathrm{O}_{3}-84100 \%$ Volatility & 1.547 & 952.26 & 30.35 & 0.672 & - \\
\hline & & & & & \\
\hline 2.0 wt\% B $\mathbf{O}_{3}$ & & & & & \\
\hline SB7b-May $\mathrm{B}_{2} \mathrm{O}_{3}-200100 \%$ Retention & 1.422 & 968.77 & 30.52 & 0.673 & - \\
\hline SB7b-May $\mathrm{B}_{2} \mathrm{O}_{3}-200100 \%$ Volatility & 1.404 & 968.77 & 32.41 & 0.673 & - \\
\hline SB7b-May-ARP B $\mathrm{B}_{2} \mathrm{O}_{3}-200100 \%$ Retention & 1.555 & 949.33 & 29.12 & 0.674 & - \\
\hline SB7b-May-ARP $\mathrm{B}_{2} \mathrm{O}_{3}-200100 \%$ Volatility & 1.537 & 949.33 & 30.93 & 0.674 & - \\
\hline \hline
\end{tabular}

First consider the May-based SB7b sludge-only projections assuming 100\% retention and 100\% volatilization (first two rows of Table 13). The predicted properties and MAR status for these two options are identical - as they should be. Under these flowsheet conditions, there is no contribution of $\mathrm{B}_{2} \mathrm{O}_{3}$ from the SE so the computed glass compositions are identical. The results of the May-based SB7b sludge-only projections with the addition of $0.84 \mathrm{wt} \% \mathrm{~B}_{2} \mathrm{O}_{3}$ from the SE 
assuming $100 \%$ retention and $100 \%$ volatilization are shaded in Table 13 . A review of the predicted properties shows only minor changes relative to the sludge-only baseline flowsheet regardless of the degree of volatility assumed. For example, consider the predictions associated with the assumptions of $100 \%$ retention and $100 \%$ volatility of the $0.84 \mathrm{wt} \% \mathrm{~B}_{2} \mathrm{O}_{3}$ in the sludgeonly flowsheet. The normalized boron release (NL [B]) values for these two glasses are 1.420 $\mathrm{g} / \mathrm{L}$ and $1.412 \mathrm{~g} / \mathrm{L}$ respectively. Predictions of liquidus temperature $\left(\mathrm{T}_{\mathrm{L}}\right)$ and calculated nepheline values are identical regardless of $\mathrm{B}_{2} \mathrm{O}_{3}$ retention (from the $\mathrm{SE}$ ) assumptions. As with the durability predictions, small differences also exist for the predicted viscosity values (31.03 versus 31.82 Poise for $100 \%$ retention and $100 \%$ volatility, respectively). These results indicate that the predicted properties of glasses that would result if $0 \%$ or $100 \%$ of the $\mathrm{B}_{2} \mathrm{O}_{3}$ from the SE were retained are essentially identical. Based on these predicted properties at $40 \% \mathrm{WL}$, there would be no difference in SME acceptability decisions for any of the sludge-only based flowsheet options regardless of $\mathrm{B}_{2} \mathrm{O}_{3}$ volatility.

A review of the coupled operations flowsheets in Table 13 show similar results to the sludge-only based options. Very minor differences are predicted in the four major glass properties regardless of the assumptions made with respect to $\mathrm{B}_{2} \mathrm{O}_{3}$ volatility. In addition to essentially constant predicted properties, the MAR status suggests that SME acceptability decisions would be identical as well at $40 \% \mathrm{WL}{ }^{6}$

Given the differences in the predicted properties are very minor and decisions regarding SME acceptability are identical regardless of assumptions made with respect to $\mathrm{B}_{2} \mathrm{O}_{3}$ volatility (e.g., the $0.84 \mathrm{wt} \% \mathrm{~B}_{2} \mathrm{O}_{3}$ contribution from the $\mathrm{SE}$ ), the authors also evaluated the possible impact of 2 $\mathrm{wt} \% \mathrm{~B}_{2} \mathrm{O}_{3}$ added to the May-based sludge options. The results of this assessment are also shown in Table 13. As expected, there is a larger difference in the predicted properties with the complete retention or volatilization of $\mathrm{B}_{2} \mathrm{O}_{3}$ as compared to the $0.84 \mathrm{wt} \%$ results. However, these differences are still very minor and have no impact on SME acceptability decisions at $40 \% \mathrm{WL}$.

It is noted that the predicted properties and MAR status shown in Table 13 are based on glasses targeting 40\% WL. Although these results indicate no difference in SME acceptability decisions, perhaps just as important the demonstration that the assumptions regarding $\mathrm{B}_{2} \mathrm{O}_{3}$ volatility (from the SE contribution) do not affect decisions over a larger WL interval. Table 14 shows the results of a MAR assessment for the same May-based sludge options coupled with Frit 418 over a WL interval from $32-42 \%$. The results of this assessment suggest that decisions regarding acceptability of the glass are independent of the sludge option and volatility assumptions made when Frit 418 is used. That is, all of the glasses covering a WL of 32 to $42 \% \mathrm{WL}$ are classified as acceptable for combinations of sludge-only, coupled operations, and $\mathrm{B}_{2} \mathrm{O}_{3}$ volatility assumptions up to $2 \mathrm{wt} \% \mathrm{~B}_{2} \mathrm{O}_{3}$ in sludge (from the $\mathrm{SE}$ ).

\footnotetext{
${ }^{6}$ It is noted that future Salt Waste Processing Facility (SWPF) operations are anticipated to transfer higher concentrations of $\mathrm{TiO}_{2}$ to the DWPF as well as employ the new solvent system assessed in this study. These changes may impact the projected operating windows for certain sludge batches relative to their sludge-only counterparts (assuming no change in frit composition to tolerate both flowsheets). Although SWPF additions to the DWPF flowsheet have not been formally addressed by a MAR assessment in this study, the impact of $\mathrm{B}_{2} \mathrm{O}_{3}$ (from the new solvent deployment in SWPF) to a SWPF-based sludge composition to the predicted glass properties would be similar to those for an ARP-based system (e.g., Table 13). More specifically, addition of $0.84 \mathrm{wt} \%$ (up to $2 \mathrm{wt} \%$ ) $\mathrm{B}_{2} \mathrm{O}_{3}$ to a SWPF-based flowsheet would have very minimal impacts on the predicted glass properties and SME acceptability decisions as compared to the SWPF-based flowsheet without additions of $\mathrm{B}_{2} \mathrm{O}_{3}$ from the SE. Assessment of the $\mathrm{TiO}_{2}$ impact from the SWPF flowsheet is outside the bounds of this study.
} 
Table 14. MAR Status for $100 \%$ Retention and $100 \%$ Volatility of $\mathrm{B}_{2} \mathrm{O}_{3}$ from the SE over WLs of $32-42 \%$ for the May-Based SB7b Projections.

\begin{tabular}{||c|c||}
\hline \multicolumn{1}{|c|}{ Sludge Type } & $\begin{array}{c}\text { MAR Status from } \\
\mathbf{3 2 - 4 2 \%} \text { WL }\end{array}$ \\
\hline Sludge-Only & acceptable \\
\hline SB7b-May $100 \%$ Retention & acceptable \\
\hline SB7b-May $100 \%$ Volatility & acceptable \\
\hline SB7b-May $\mathrm{B}_{2} \mathrm{O}_{3}-0.84100 \%$ Retention & acceptable \\
\hline SB7b-May $\mathrm{B}_{2} \mathrm{O}_{3}-0.84100 \%$ Volatility & \\
\hline ARP & acceptable \\
\hline SB7b-May ARP $100 \%$ Retention & acceptable \\
\hline SB7b-May $\mathrm{ARP}_{100 \% \text { Volatility }}$ & acceptable \\
\hline SB7b-May ARP $\mathrm{B}_{2} \mathrm{O}_{3}-0.84100 \%$ Retention & acceptable \\
\hline SB7b-May-ARP $\mathrm{B}_{2} \mathrm{O}_{3}-0.84100 \%$ Volatility & \\
\hline & \\
\hline 2.0 wt \% $\mathbf{B}_{2} \mathrm{O}_{3}$ & acceptable \\
\hline SB7b-May $\mathrm{B}_{2} \mathrm{O}_{3}-2.0100 \%$ Retention & acceptable \\
\hline SB7b-May $\mathrm{B}_{2} \mathrm{O}_{3}-2.0100 \%$ Volatility & acceptable \\
\hline SB7b-May-ARP $\mathrm{B}_{2} \mathrm{O}_{3}-2.0100 \%$ Retention & acceptable \\
\hline SB7b-May-ARP $\mathrm{B}_{2} \mathrm{O}_{3}-2.0100 \%$ Volatility & \\
\hline
\end{tabular}

Although no major changes in the predicted glass properties and no change to SME acceptability decisions over a WL interval of 32 to $42 \%$ regardless of the assumptions made regardless $\mathrm{B}_{2} \mathrm{O}_{3}$ volatility (contribution from the SE up to $2 \mathrm{wt} \%$ for the SB7b May-based flowsheets), other operational considerations should be addressed. For example, if the $\mathrm{B}_{2} \mathrm{O}_{3}$ contribution from the SE does volatilize during melter processing, the ability of the off-gas system to handle this additional flux should be assessed. In addition, considerations regarding potential boron volatility from the SE should be accounted for in the variability study supporting waste qualification efforts.

With the $0.01 \mathrm{M}$ boric acid flowsheet, the MAR assessments suggest that the $\mathrm{B}_{2} \mathrm{O}_{3}$ contributions for the SE are so minor that decisions regarding SME acceptability or values of predicted properties are not affected over the entire spectrum of volatility assumptions ( 0 to 100\%). However, if the molarity of the boric acid flowsheet is increased above $0.01 \mathrm{M}$, the ramifications on predicted properties and SME acceptability decisions could become more serious.

\section{Variation Stage Assessment}

To assess the impact of sludge variation on the projected operating windows, sludge extreme vertices (EVs) were developed based on the "min of the mins" and "max of the maxs" for all $\mathrm{SB} 7 \mathrm{~b}$ sludge options ranging from $0 \% \mathrm{~B}_{2} \mathrm{O}_{3}$ to $2 \mathrm{wt} \% \mathrm{~B}_{2} \mathrm{O}_{3}$. For each of the major components (e.g., $\mathrm{Al}_{2} \mathrm{O}_{3}, \mathrm{Fe}_{2} \mathrm{O}_{3}, \mathrm{U}_{3} \mathrm{O}_{8}$, etc), $\pm 7.5 \%$ was added to the minimum and maximum contents from 
all sludge options. For each minor component, $\pm 0.5 \mathrm{wt} \%$ was added to the minimum and maximum concentrations from all sludge options. For $\mathrm{SO}_{4}, \pm 0.1 \mathrm{wt} \%$ was added to the minimum and maximum concentrations from all sludge options. The $\mathrm{B}_{2} \mathrm{O}_{3}$ values remained fixed at 0 and $2.0 \mathrm{wt} \%$ for the EVs. These minimum and maximum values were then used to create 9186 sludge compositions (or extreme vertices). Each sludge EV was then coupled with Frit 418 and Frit $418-7 \mathrm{D}$ over a WL interval of $25-50 \% \mathrm{WL}$ to compute glass compositions. Those glass compositions were then used as input to complete a Variation Stage MAR assessment. The objective of the Variation Stage is to evaluate how robust each frit is to potential compositional variation within the SB7b region of interest - including additions of boric acid up to $2 \mathrm{wt} \%$.

Table 15 summarizes the results of the Variation Stage assessment. The projected operating windows for Frit 418 and Frit 418-7D are $25-37 \%$ WL with predictions of $\mathrm{T}_{\mathrm{L}}$ limiting access to higher WLs. These results are consistent with typical Variation Stage assessment in the fact that once sludge variation is applied $4-6 \mathrm{WL}$ percentage points are typically lost over which the fritsludge systems are deemed acceptable. The results of this assessment indicate no difference between the two frits with respect to tolerating compositional variation in potential SB7b projections. Although no differences are observed with respect to the projected operating windows, another critical item to point out is that these frits continue to demonstrate the ability to tolerate potential flowsheet changes among sludge-only, coupled operations, and boric acid additions. That is, the ability to handle the 0 to $2 \mathrm{wt} \% \mathrm{~B}_{2} \mathrm{O}_{3}$ additions over this operating range shows that trim additions to the SRAT may not be required even if the boric acid based SE is not added to the SRAT. This latter statement does not address the need for a $\mathrm{B}_{2} \mathrm{O}_{3}$ trim tank to maintain $\mathrm{B}_{2} \mathrm{O}_{3}$ concentrations in glass high enough to be considered a borosilicate glass. As previously discussed, there is no need to have a trim tank based on the $0.01 \mathrm{M}$ boric acid baseline flowsheet.

Table 15. Variation Stage MAR Assessments for Frit 418 and Frit 418-7D.

\begin{tabular}{|c|c||}
\hline Frit & $\begin{array}{c}\text { Projected Operating } \\
\text { Window (WL) }\end{array}$ \\
\hline 418 & $25-37$ \\
& $\mathrm{~T}_{\mathrm{L}}$ \\
\hline $418-7 \mathrm{D}$ & $25-37$ \\
& $\mathrm{~T}_{\mathrm{L}}$ \\
\hline
\end{tabular}

\section{Impact of Frit 418 Specifications on Projected Operating Windows}

The previous MAR assessments have assumed a nominal Frit 418 and Frit 418-7D composition. However, when DWPF procures Frit 418 from an outside vendor, compositional specifications are provided and ultimately used to assess acceptability of the frit from the vendor. Table 16 summarizes the current compositional specifications associated with Frit 418. The nominal composition of Frit 418-7D is also shown in Table 16. It is interesting to note that nominal composition of Frit 418-7D lies within the current Frit 418 specifications. Therefore, DWPF may have already procured and/or processed a Frit 418-7D-like composition. However, the authors 
wanted to assess the impact of applying the current frit specifications on the projected operating windows for all of the SB7b nominal sludge compositions. To support this assessment, EVs in frit space were developed based on the minimum and maximum values for each oxide as defined by the current specifications. Twelve EV-based Frit 418 compositions were developed.

Table 16. Nominal Compositions (wt \%) of Frit 418 and Frit 418-7D with current Frit Specifications for Frit 418.

\begin{tabular}{||c|c|c||}
\hline \hline Oxide & Frit 418 & Frit 418-7D \\
\hline $\mathbf{B}_{\mathbf{2}} \mathbf{O}_{3}$ & $8 \pm 0.65$ & 7.44 \\
\hline $\mathbf{L i}_{2} \mathbf{O}$ & $8 \pm 0.55$ & 8.05 \\
\hline $\mathbf{N a}_{\mathbf{2}} \mathbf{O}$ & $8 \pm 0.55$ & 8.05 \\
\hline $\mathrm{SiO}_{\mathbf{2}}$ & $76 \pm 1.3$ & 76.46 \\
\hline
\end{tabular}

Table 17 and Table 18 summarize the MAR assessments based on the twelve EV-based Frit 418 compositions. In addition to the projected operating window the constraint limiting access to higher WLs is identified along with the number of EVs (out of 12) that fail at the next WL. For example, consider the April sludge-only projection. The projected operating window over which all 12 Frit 418 EVs could be processed is $25-40 \%$ WL with predictions of low $\eta$ limiting access to higher WLs. Two of the twelve frit EVs fail low viscosity at $41 \%$ WL. A quick review of the information shown in Table 17 shows that all of the Frit 418 EVs can process all of the April SB7b nominal projections from 25\% WL to at least 39\% WL. As with previous MAR assessments, this demonstrates the ability of the Frit 418 (and the compositional region defined by its EVs) to process all of the April SB7b options regardless of the introduction of $\mathrm{B}_{2} \mathrm{O}_{3}$ concentrations ranging from $0 \mathrm{wt} \%$ to $2 \mathrm{wt} \%$ from the SE. Similar results are shown for the May SB7b sludge options as shown in Table 18. 
Table 17. Projected Operating Windows for Frit 418 EVs for April-Based SB7b Projections.

\begin{tabular}{||l|c||}
\hline \multicolumn{1}{|c|}{ Sludge Option } & Frit 418 EVs \\
\hline SB7b April & $\begin{array}{c}25-40 \\
\text { low } \eta(2)\end{array}$ \\
\hline SB7b April $\mathbf{B}_{2} \mathbf{O}_{3}: \mathbf{0 . 8 4}$ & $\begin{array}{c}25-39 \\
\text { low } \eta(1)\end{array}$ \\
\hline SB7b April $\mathbf{B}_{\mathbf{2}} \mathbf{O}_{\mathbf{3}}: \mathbf{0 . 9 0}$ & $\begin{array}{c}25-39 \\
\text { low } \eta(1)\end{array}$ \\
\hline SB7b April $\mathbf{B}_{2} \mathbf{O}_{3}: \mathbf{1 . 0}$ & $\begin{array}{c}25-39 \\
\text { low } \eta(1)\end{array}$ \\
\hline SB7b April $\mathbf{B}_{\mathbf{2}} \mathbf{O}_{3}: \mathbf{2 . 0}$ & $\begin{array}{c}25-39 \\
\text { low } \eta(1)\end{array}$ \\
\hline SB7b April ARP & $\begin{array}{c}25-39 \\
\text { low } \eta(2)\end{array}$ \\
\hline SB7b April ARP $\mathbf{B}_{\mathbf{2}} \mathbf{O}_{3}: \mathbf{0 . 8 4}$ & $\begin{array}{c}25-39 \\
\text { low } \eta(2)\end{array}$ \\
\hline SB7b April ARP $\mathbf{B}_{\mathbf{2}} \mathbf{O}_{3}: \mathbf{0 . 9 0}$ & $\begin{array}{c}25-39 \\
\text { low } \eta(2)\end{array}$ \\
\hline SB7b April ARP $\mathbf{B}_{\mathbf{2}} \mathbf{O}_{3}: \mathbf{1 . 0}$ & $\begin{array}{c}25-39 \\
\text { low } \eta(2)\end{array}$ \\
\hline SB7b April ARP $\mathbf{B}_{\mathbf{2}} \mathbf{O}_{3}: \mathbf{2 . 0}$ & $\begin{array}{c}25-39 \\
\text { low } \eta(1)\end{array}$ \\
\hline
\end{tabular}


SRNL-STI-2011-00110

Revision 0

Table 18. Projected Operating Windows for Frit 418 EVs for May-Based SB7b Projections.

\begin{tabular}{|c|c|}
\hline Sludge Option & Frit 418 EVs \\
\hline SB7b May & $\begin{array}{c}25-39 \\
\text { low } \eta(1)\end{array}$ \\
\hline SB7b May $\mathrm{B}_{2} \mathrm{O}_{3}: 0.84$ & $\begin{array}{c}25-39 \\
\text { low } \eta(1)\end{array}$ \\
\hline SB7b May $\mathrm{B}_{2} \mathrm{O}_{3}: 0.90$ & $\begin{array}{c}25-39 \\
\text { low } \eta(1)\end{array}$ \\
\hline SB7b May $\mathrm{B}_{2} \mathrm{O}_{3}: 1.0$ & $\begin{array}{c}25-39 \\
\text { low } \eta(1)\end{array}$ \\
\hline SB7b May $\mathrm{B}_{2} \mathrm{O}_{3}: 2.0$ & $\begin{array}{c}25-39 \\
\text { low } \eta(2)\end{array}$ \\
\hline SB7b May ARP & $\begin{array}{c}25-39 \\
\text { low } \eta(2)\end{array}$ \\
\hline SB7b May ARP $B_{2} O_{3}: 0.84$ & $\begin{array}{c}25-38 \\
\text { low } \eta(1)\end{array}$ \\
\hline SB7b May ARP $\mathrm{B}_{2} \mathrm{O}_{3}: 0.90$ & $\begin{array}{c}25-38 \\
\text { low } \eta(1)\end{array}$ \\
\hline SB7b May ARP $B_{2} O_{3}: 1.0$ & $\begin{array}{c}25-38 \\
\text { low } \eta(1)\end{array}$ \\
\hline SB7b May ARP $B_{2} O_{3}: 2.0$ & $\begin{array}{c}25-38 \\
\text { low } \eta(1) \\
\end{array}$ \\
\hline
\end{tabular}

\section{Impact $\mathrm{B}_{2} \mathrm{O}_{3}$ Reduction on Frit Melt Temperatures}

In this section, an experimental evaluation is performed to gain insight into the potential impacts of reduced $\mathrm{B}_{2} \mathrm{O}_{3}$ contents on the nominal melting temperatures of candidate frits for $\mathrm{SB} 7 \mathrm{~b}$ processing. Three frits were used to support this assessment. Frit 418 and Frit 418-7D were of primary interest given these frits are candidates for SB7b processing and/or were compositionally designed to offset the $6.9 \%$ of frit $\mathrm{B}_{2} \mathrm{O}_{3}$ content which could be introduced into the $\mathrm{SB} 7 \mathrm{~b}$ flowsheet based on calculations from Stone [2010]. In addition to these two frits, Frit 418-75D was developed representing a $75 \%$ reduction in the nominal Frit $418 \mathrm{~B}_{2} \mathrm{O}_{3}$ content (i.e., $75 \%$ of 8 wt\%). Table 19 summarizes the nominal compositions of these three frits. It should be noted that the compositional adjustments to Frit 418-75D far exceed those required for the maximum $0.01 \mathrm{M}$ baseline flowsheet. In fact, using the calculations by Stone [2010], compositional compensations for this frit would cover all of the options outlined for a $0.1 \mathrm{M}$ boric acid flowsheet; up to 30,000 liters of SE added to the SRAT for a $0.25 \mathrm{M}$ boric acid flowsheet; and up to 15,000 liters of SE added to the SRAT under a $0.5 \mathrm{M}$ boric acid flowsheet. Experimental evaluations of this frit will provide insight into melt temperatures for significant reductions in $\mathrm{B}_{2} \mathrm{O}_{3}$ content from the nominal Frit 418 composition as required by the TTR. 
Table 19. Nominal Compositions of Frit 418, Frit 418-7D, and Frit 418-75D.

\begin{tabular}{||c|c|c|c||}
\hline \hline Oxide & Frit 418 & Frit 418-7D & Frit 418-75D \\
\hline $\mathbf{B}_{\mathbf{2}} \mathbf{O}_{3}$ & 8 & 7.44 & 2 \\
\hline $\mathbf{L i}_{2} \mathbf{O}$ & 8 & 8.05 & 8.52 \\
\hline $\mathbf{N a}_{2} \mathbf{O}$ & 8 & 8.05 & 8.52 \\
\hline $\mathrm{SiO}_{2}$ & 76 & 76.46 & 80.96 \\
\hline
\end{tabular}

As defined in the TTQAP, reagent grade oxide and carbonates were used to target 150 grams of glass for each of the three nominal frit compositions shown in Table 19. The raw materials were thoroughly mixed and placed into platinum-alloy, $250 \mathrm{~mL}$ crucibles. The batch was placed into a high-temperature furnace at a nominal melt temperature for approximately 1 hour. After the 1 hour isothermal hold, the crucible was removed and the glass was poured (or an attempt was made to pour) onto a clean stainless plate. A series of melt temperatures were used to support this assessment. Initial melt temperatures were nominally $1150{ }^{\circ} \mathrm{C}$. After an hour isothermal hold, the batches were not homogeneous (i.e., unreacted batch was visually apparent) and it was obvious that higher melt temperatures would be required for all three frits. The furnace was ramped to $1250{ }^{\circ} \mathrm{C}$ (using the same batched materials) and held for an additional hour. After the isothermal hold at $1250^{\circ} \mathrm{C}$, each glass (or frit) was poured onto a stainless steel plate. Based on the pour rates, the viscosities of these glasses were relatively high with Frit 418-75D being the most viscous. Unreacted feed was observed in all three melts (more than likely undissolved $\mathrm{SiO}_{2}$ ) so a decision was made to increase the melt temperature to $1300{ }^{\circ} \mathrm{C}$.

New batches were prepared targeting each of the three nominal frit compositions. The batches were thoroughly mixed and placed into clean platinum-alloy crucibles which were inserted into the resistance heated furnace at $1300{ }^{\circ} \mathrm{C}$. After one hour of melting, all three glasses were poured onto a clean stainless plate. Undissolved solids were not noticed in any of the resulting pour patties. There was an obvious difference in the viscosity of Frit 418-75D relative to Frit 418 and Frit 418-7D during the pours. Frit 418-75D appeared more viscous which ultimately resulted in a thicker pour patty (i.e., the glass did not flow easily onto the stainless plate). There was no visual difference in the viscosity (or how the glass poured) between Frit 418 and Frit 418-7D. This is not surprising since the compositions are extremely similar. In fact, Frit 418-7D is within the current Frit 418 vendor compositional specifications and one would expect these two frits to behave very similarly.

Coupling the fact that Frit 418 is currently produced by both DWPF frit vendors (Bekeson Glass and Ferro Corporation) with the melt temperatures and visual observations between Frit 418 and Frit 418-7D, there should not be any issues with fabrication of Frit 418-7D. Both frits melted at $1300{ }^{\circ} \mathrm{C}$ within one hour with no visual differences in viscosity during pouring. As previously mentioned, this would be anticipated based on the minimal compositional differences between these two frits.

Although Frit 418-75D is well outside the compositional adjustments that would be required for the $0.01 \mathrm{M}$ boric acid baseline flowsheet, there was a distinct visual difference in the viscosity of this melt (at $1300{ }^{\circ} \mathrm{C}$ ) relative to Frit 418 and Frit 418-7D. Not knowing the nominal melt temperatures used by the current vendors to fabricate Frit 418 or maximum temperature capability using their current melter technologies, quantitative viscosity measurements were made on Frit 418 and Frit 418-75D to provide more detailed information on these differences in case significant reductions in $\mathrm{B}_{2} \mathrm{O}_{3}$ are required at a future date. Visual observations of viscosity 
differences are subjective and provide no real technical baseline from which to gage differences in melt temperature. Providing relative viscosities at a fixed temperature or temperature differences to obtain a fixed viscosity could be used by a vendor to ascertain if the frit composition could be produced within the existing melter technology.

The viscosities of Frit 418 and Frit 418-75D were measured following Procedure A of the ASTM C 965 standard [ASTM (2007)]. An Orton high temperature rotating spindle viscometer was used with platinum crucibles and spindles. Viscosities were measured over a temperature range of $1275^{\circ} \mathrm{C}$ to $1375^{\circ} \mathrm{C}$ for both frits. The measured data were fit to a Fulcher equation [Fulcher (1925)] to provide a measured viscosity value at $1300{ }^{\circ} \mathrm{C}$. Table 20 summarizes measured viscosities (based on the Fulcher equation results) at $1300{ }^{\circ} \mathrm{C}$ for both Frit 418 and Frit 418-75D. These data indicate that the viscosity of the $\mathrm{B}_{2} \mathrm{O}_{3}$-deficient Frit $418-75 \mathrm{D}$ at $1300{ }^{\circ} \mathrm{C}$ is about a factor of 2 greater than that of Frit 418 at the same temperature. Although this agrees with visual observations (i.e., Frit 418-75D being "thicker"), the information could be used by the vendor to assess the potential production of Frit 418-75D with their current melter technology. Another data point of interest is the temperature at which the viscosity measurements were almost the same. That is, if the vendor uses viscosity as a production control, then at what temperature is the viscosity of the Frit $418-75 \mathrm{D}$ system equivalent to the viscosity at $1300{ }^{\circ} \mathrm{C}$ (or 54.4 Poise)? Based on the measured data, the measured viscosity for Frit $418-75 \mathrm{D}$ was 60.4 Poise at $1374{ }^{\circ} \mathrm{C}$. Although not exactly the same 54.4 Poise, this suggests that if the vendor wants to maintain a constant viscosity, temperatures in excess of $1375^{\circ} \mathrm{C}$ would be required to manufacture Frit 418 $75 \mathrm{D}$.

Table 20. High Temperature Viscosity Measurements for Frit 418.

\begin{tabular}{||c|c||}
\hline Frit & Viscosity (Poise) \\
\hline 418 & 54.4 \\
\hline $418-75 \mathrm{D}$ & 99.9 \\
\hline
\end{tabular}

\section{Summary}

As a part of the ARP/MCU Life Extension Project, a next generation solvent (NG-CSSX), a new strip acid, and modified monosodium titanate (mMST) will be deployed. The strip acid will be changed from dilute nitric acid to a dilute boric acid stream $(0.01 \mathrm{M})$. To support programmatic objectives, the downstream impacts of the boric acid strip effluent (SE) to the glass formulation activities and melter operations are considered in this study. More specifically, the impacts of boric acid additions to the projected SB7b operating windows, potential impacts to frit production temperatures, and the potential impact of boron volatility are evaluated. The impacts to CPC processing will be documented in a separate report. The baseline flowsheet used to support this assessment was a $0.01 \mathrm{M}$ boric acid stream. As warranted, increased levels of boric acid $\left(\mathrm{B}_{2} \mathrm{O}_{3}\right)$ additions were also evaluated but these higher concentrations should be considered outside the current baseline flowsheet.

Key areas to be addressed in this report are associated with the potential impact of the new SE (boric acid) on DWPF glass formulation include: (1) ensuring potential impacts to future SME acceptability decisions are identified and, if warranted, outlining strategies or approaches to 
technically address those impacts, (2) assessing the robustness of the candidate frits to potential sludge compositional variations (sludge-only operations, coupled operations based on ARP additions, and/or introduction of the new SE into the DWPF flowsheet), (3) evaluating the impact of potential boric acid (or boron) volatility during vitrification of the SME product or during melter processing on key glass properties or SME acceptability decisions, and (4) evaluating the impact on the nominal melting temperatures of candidate frit compositions that may require compositional alterations (e.g., reduction in $\mathrm{B}_{2} \mathrm{O}_{3}$ content) to account for the new SE. The results of this study are summarized below based on the key questions.

The study was primarily supported by the use of SB7b projections provided by SRR in January 2011 as well as the addition of $0.84 \mathrm{wt} \% \mathrm{~B}_{2} \mathrm{O}_{3}$ to each nominal sludge composition to account for the maximum $\mathrm{B}_{2} \mathrm{O}_{3}$ contribution from the $\mathrm{SE}$ as defined by Stone [2010] for the $0.01 \mathrm{M}$ flowsheet at a fixed WL (40\%). To gain further insight into the potential impact of the new SE on glass formulation activities, higher $\mathrm{B}_{2} \mathrm{O}_{3}$ concentrations were evaluated in this study. It must be noted that the results from these higher concentrations are considered for information only and should not be used to make or question decisions based on the current $0.01 \mathrm{M}$ boric acid baseline flowsheet.

\section{MAR Assessments}

Based on the 1-20-11 SB7b projections and the results of the MAR assessments, Frit 418 and Frit 418-7D are robust to the implementation of the $0.01 \mathrm{M}$ boric acid SE into the SB7b flowsheet (sludge-only or ARP-added). The projected operating windows for the nominal SB7b projections remain essentially constant (i.e., $25-43$ or $25-44 \%$ WL) regardless of the flowsheet options (i.e., sludge-only, ARP, and the presence of the new SE). These results indicate that even if SE is not transferred to the SRAT, there would not be a need to add boric acid from a trim tank to compensate for the absence of the boron-containing SE in either a sludge-only or coupled SB7b flowsheet.

\section{Boron Volatility}

With respect to boron volatility, the MAR assessments also suggest that SME acceptability decisions would not be different assuming either $100 \%$ of the $\mathrm{B}_{2} \mathrm{O}_{3}$ from the SE were retained or volatilized. More specifically, the $0.84 \mathrm{wt} \% \mathrm{~B}_{2} \mathrm{O}_{3}$ in the $\mathrm{SE}$ is so minor that its presence in the SME analysis does not influence SME acceptability decisions.

\section{Impact of $\mathrm{B}_{2} \mathrm{O}_{3}$-Deficient Frits on Melt Temperatures}

Based on the $0.01 \mathrm{M}$ boric acid flowsheet, there is very little difference between Frit 418 and Frit 418-7D (a frit that was compositionally altered to account for the $0.84 \mathrm{wt} \% \mathrm{~B}_{2} \mathrm{O}_{3}$ in the $\mathrm{SE}$ ) with respect to melt temperature. In fact, when one evaluates the compositions of Frit 418-7D, it lies within the current Frit 418 vendor specifications and therefore could have been produced by the vendor targeting the nominal composition of Frit 418.

It was shown that if significantly lower $\mathrm{B}_{2} \mathrm{O}_{3}$ concentration frits (e.g., Frit 418-75D) are required to account for a higher molarity $\mathrm{SE}$, this could require higher processing temperatures to maintain a fixed viscosity relative to Frit 418. 


\section{Recommendations}

The following recommendations are made based on the results of this study (using the $0.01 \mathrm{M}$ flowsheet as the baseline):

Continue to evaluate the use of Frit 418 or alternative frits with higher $\mathrm{B}_{2} \mathrm{O}_{3}$ concentrations based on anticipated revised projections for SB7b. As mentioned, Frit 418 is a viable candidate based on the 1-20-11 SB7b projections from SRR but revised compositions may render Frit 418 infeasible from a projected operating window perspective (to meet contractual WL goals).

$>$ Based on the $0.01 \mathrm{M}$ boric acid flowsheet, there is no need for a $\mathrm{B}_{2} \mathrm{O}_{3}$ trim tank to account for SB7b flowsheet conditions in which the SE is not added. That is, the MAR results suggest that flowsheets without the $\mathrm{SE}$ added do not require a $\mathrm{B}_{2} \mathrm{O}_{3}$ trim to maintain predicted properties or consistent projected operating windows. This is coupled with the fact that the $\mathrm{B}_{2} \mathrm{O}_{3}$ concentration in the Frit $418(8 \mathrm{wt} \%)$ is the lowest $\mathrm{B}_{2} \mathrm{O}_{3}$ concentration (in frit) that DWPF is anticipated to process. With higher $\mathrm{B}_{2} \mathrm{O}_{3}$ containing frits, the amount of the boron from the $\mathrm{SE}$ as a percentage of the boron in the frit becomes more negligible.

$>$ If the molarity of the boric acid flowsheet is increased above $0.01 \mathrm{M}$, the ramifications on predicted properties and SME acceptability decisions could become more serious warranting additional evaluations.

\section{References}

ASTM. 2007. "Standard Practice for Measuring Viscosity of Glass Above the Softening Point," ASTM C-965, (2007).

Bricker, JM. 2010. Testing for ARP/MCU Life Extension Project - DWPF, HLW-DWPFTTR-2010-0045, Savannah River Remediation, December 2010.

Fulcher, G.S. 1925. "Analysis of Recent Measurements of the Viscosity of Glasses," Journal of the American Ceramic Society, 8 [6] 339-355 (1925).

Fulcher, G.S. 1925. "Analysis of Recent Measurements of the Viscosity of Glasses, II," Journal of the American Ceramic Society, 8 [12] 789-794 (1925).

Peeler, DK and TB Edwards. 2005. "Frit Development Effort for SB4: Nominal and Variation Stage Assessments," U.S. Department of Energy Report WSRC-TR-2005-00372, Revision 0, Westinghouse Savannah River Company, Aiken, SC (2005).

Newell, JD and DK Peeler. 2011. Task Technical and Quality Assurance Plan for Evaluation of DWPF Impacts of Boric Acid Use in Cesium Strip for SWPF and MCU, SRNL-RP-201001732, Savannah River National Laboratory, Aiken, South Carolina, January 2011.

Stone, ME. 2010. Preliminary Evaluation of DWPF Impacts of Boric Acid Use in Cesium Strip for SWPF and MCU, SRNL-STI-2010-00594, Savannah River National Laboratory, Aiken, South Carolina, September 2010. 


\section{Distribution:}

\begin{tabular}{|l|l|}
\hline J.W. Amoroso, 999-W & P.R. Jackson, 703-46A \\
A.B. Barnes, 999-W & F.C. Johnson, 999-W \\
D.R. Best, 999-W & D.C. Koopman, 999-W \\
A.L. Billings, 999-W & D.P. Lambert, 999-W \\
J.M. Bricker, 704-27S & D.H. McKenzie, 241-197H \\
D.A. Crowley, 773-43A & S.L. Marra, 773-A \\
R.E. Edwards, 773-67A & J.D. Newell, 999-W \\
T.B. Edwards, 999-W & B.A. Oard, 241-197H \\
T.L. Fellinger, 704-26S & J.E. Occhipinti, 704-S \\
S.D. Fink, 773-A & D.K. Peeler, 999-W \\
K.M. Fox, 999-W & F.M. Pennebaker, 773-42A \\
M.W. Geeting, 241-152H & H.M. Pittman, 704-27S \\
B.A. Gifford, 704-56H & J.W. Ray, 704-S \\
J.M. Gillam, 766-H & H.B. Shah, 766-H \\
M.S. Hay, 773-42A & D.C. Sherburne, 704-S \\
C.C. Herman, 999-W & M.E. Smith, 704-30S \\
E.W. Holtzscheiter, 704-15S & A.V. Staub, 704-27S \\
R.N. Hinds, 704-S & M.E. Stone, 999-W \\
J.F. Iaukea, 704-30S & J.P. Vaughan, 773-41A \\
& K.H. Subramanian, 766-H \\
& J.R. Zamecnik, 999- \\
& \\
\hline
\end{tabular}

